\title{
The Alveolate Perkinsus marinus: Biological Insights from EST Gene Discovery
}

\author{
Sandeep J Joseph¹,2,5, José A Fernández-Robledoł3, Malcolm J Gardner4,6, Najib M El-Sayed4,7, Chih-Horng Kuo2,8, \\ Eric J Schott 3,9 , Haiming Wang ${ }^{1}$, Jessica C Kissinger*1,2 and Gerardo R Vasta*3
}

\begin{abstract}
Background: Perkinsus marinus, a protozoan parasite of the eastern oyster Crassostrea virginica, has devastated natural and farmed oyster populations along the Atlantic and Gulf coasts of the United States. It is classified as a member of the Perkinsozoa, a recently established phylum considered close to the ancestor of ciliates, dinoflagellates, and apicomplexans, and a key taxon for understanding unique adaptations (e.g. parasitism) within the Alveolata. Despite intense parasite pressure, no disease-resistant oysters have been identified and no effective therapies have been developed to date.

Results: To gain insight into the biological basis of the parasite's virulence and pathogenesis mechanisms, and to identify genes encoding potential targets for intervention, we generated $>31,0005^{\prime}$ expressed sequence tags (ESTs) derived from four trophozoite libraries generated from two P. marinus strains. Trimming and clustering of the sequence tags yielded 7,863 unique sequences, some of which carry a spliced leader. Similarity searches revealed that 55\% of these had hits in protein sequence databases, of which 1,729 had their best hit with proteins from the chromalveolates (E-value $\leq 1 \mathrm{e}-5$ ). Some sequences are similar to those proven to be targets for effective intervention in other protozoan parasites, and include not only proteases, antioxidant enzymes, and heat shock proteins, but also those associated with relict plastids, such as acetyl-CoA carboxylase and methyl erythrithol phosphate pathway components, and those involved in glycan assembly, protein folding/secretion, and parasite-host interactions.

Conclusions: Our transcriptome analysis of P. marinus, the first for any member of the Perkinsozoa, contributes new insight into its biology and taxonomic position. It provides a very informative, albeit preliminary, glimpse into the expression of genes encoding functionally relevant proteins as potential targets for chemotherapy, and evidence for the presence of a relict plastid. Further, although P. marinus sequences display significant similarity to those from both apicomplexans and dinoflagellates, the presence of trans-spliced transcripts confirms the previously established affinities with the latter. The EST analysis reported herein, together with the recently completed sequence of the $P$. marinus genome and the development of transfection methodology, should result in improved intervention strategies against dermo disease.
\end{abstract}

\section{Background}

The protozoan parasite Perkinsus marinus is a facultative intracellular parasite of mollusks, and the causative agent of "dermo" disease in both wild and farmed Eastern oyster (Crassostrea virginica) populations along the Atlantic

\footnotetext{
* Correspondence: jkissing@uga.edu, gvasta@som.umaryland.edu

${ }^{1}$ Center for Tropical and Emerging Global Diseases, University of Georgia, Athens, GA 30602, USA

3 Department of Microbiology and Immunology, University of Maryland

School of Medicine, IMET, Baltimore, MD 21202, USA

+ Contributed equally

Full list of author information is available at the end of the article
}

and Gulf coasts of the USA [1-4]. Since its initial description, $P$. marinus has generated substantial controversy with regards to its taxonomic placement [5,6]. A close relationship with the Apicomplexa was initially proposed based on the ultrastructural analysis of the zoospore, which revealed the presence of organelles resembling an apical complex [7]. Molecular evidence gathered over the following years revealed affinities with the Dinozoa [8], and even suggested this group to be its closest extant taxon $[9,10]$. More recently, however, ultrastructural similarities and molecular phylogenetic affinities to Parvilucifera sp., a parasite of microeukaryotes, led to the 
establishment of the phylum Perkinsozoa, which like the Apicomplexa, is only comprised of endoparasites [11]. This new phylum is considered to be one of the earliest diverging groups from the lineage leading to dinoflagellates, albeit close to the ancestor from which the ciliates, dinoflagellates, and apicomplexans originated [12-14].

Together with the various emerging diseases in the estuarine and marine environment [15], infections by $P$. marinus and other Perkinsus spp. are responsible for devastating losses in shellfisheries of economically relevant mollusk species worldwide, including oysters, clams, and abalone [16]. Further, given the critical role that oysters and other filter-feeding bivalves play in maintaining environmental water quality, the dramatic declines in bivalve populations, caused by dermo disease, have had correspondingly detrimental impacts on the estuarine environment. Although several intervention strategies have been implemented to control dermo disease, they have had little or no success [17]. During the early 1990s, however, the development of in vitro culture methods for $P$. marinus [18-20] provided a key resource that enabled studies leading to the identification of new targets for intervention [16]. These studies ranged from fundamental cellular, biochemical, molecular and genetic studies of $P$. marinus biology to the direct in vitro testing of potential chemotherapeutic drugs that might suppress its proliferation [21-27].

The life cycle of $P$. marinus includes a free-living motile stage (zoospore) and a non-motile vegetative stage (trophozoite). The parasite is ingested by the host during filter-feeding, and is then phagocytosed by hemocytes present in the alimentary canal. Although the infection mechanism has not been fully elucidated, once inside the host, $P$. marinus trophozoites are recognized via a galectin present on the surface of phagocytic hemocytes $[28,29]$, internalized, and localize inside phagosome-like structures. The phagocytosed trophozoites remain viable by abrogating the host's respiratory burst through their effective antioxidative machinery [30,31], and retain their proliferative capacity [32]. Hemocyte migration throughout host tissues leads to systemic infection and eventually death [6,33]. Therefore, in addition to those genes that mediate intrahemocytic survival, the trophozoite is likely to express additional genes that are involved in nutrient acquisition, proliferation, and pathogenesis.

Expressed sequence tag (EST) surveys [34] have proven to be a viable approach for gene discovery and therapeutic target identification in a variety of microbial pathogens and parasites [35-38]. EST analysis offers a rapid and valuable first glimpse of gene expression at a particular life cycle stage or under certain environmental conditions. The number of gene sequences published or available in GenBank for the genus Perkinsus is very limited, and mostly consist of ribosomal RNA (rRNA) sequences.
In this study, we analyzed 31,727 ESTs generated from trophozoites from two different $P$. marinus strains, one of which was studied in both the presence and absence of oyster serum. Grouping of the ESTs into clusters and singletons resulted in 7,863 unique sequences. Together, they provide the first broad-based molecular view into the basic biology and cellular metabolism of this protozoan parasite of unique phylogenetic position.

\section{Methods \\ Parasite cultures}

All P. marinus strains were maintained in DME: Ham's F12 (1:2) supplemented with 5\% fetal bovine serum (FBS) as reported elsewhere [39]. Two cultured strains of $P$. marinus trophozoites, CB5D4-ATCC PRA-240 (the strain used for the sequencing the $P$. marinus genome; [40]) grown in standard medium, and TXsc-ATCC 50983 [18] grown in both standard medium and medium supplemented with $C$. virginica serum (50\%), were used for RNA isolation and subsequent cDNA library and EST generation.

\section{RNA extraction and library construction}

A total of four (non-normalized) libraries were constructed using $P$. marinus trophozoites. Three libraries were constructed from strains propagated in standard culture medium (TXsc and CB5D4), and one from the TXsc strain propagated in medium supplemented with $C$. virginica oyster serum (50\%). Oyster serum was prepared as reported earlier [41]. Briefly, shells were notched at the posterior end and dorsal side of the shells, cleaned with ethanol and hemolymph drawn from the adductor muscle (approximately $2 \mathrm{ml}$ hemolymph per individual oyster) with a sterile syringe fitted with a 19-gauge needle. Hemolymph samples were centrifuged at $800 \times g$ at $4^{\circ} \mathrm{C}$ for $10 \mathrm{~min}$, the supernatant serum separated from the cell pellet, mixed at equal parts with $P$. marinus culture medium and used for the experimental cultures described above.

Perkinsus marinus TXsc cultures were centrifuged for 5 min at $490 \times g$, and RNA extracted from the pellets (1.5$2.0 \mathrm{ml}$ packed $P$. marinus trophozoites) by the guanidine isothiocyanate method [42]. One mg of total RNA was used for Poly A+ isolation and $5 \mu$ g of Poly A+ enriched $P$. marinus RNA was used to construct each $P$. marinus TXsc Lambda ZAP library following the manufacturer's instructions (Stratagene, La Jolla, CA). Each library was amplified once through Escherichia coli XL1-Blue MRF and stored at $-80^{\circ} \mathrm{C}$. Total RNA from the strain CB5D4 was extracted as above. A commercial service (Express Genomics, Frederick, MD) was used to construct the cDNA libraries. Since the libraries were not normalized and to avoid redundancy of the ESTs, a large-insert library (average insert size $2.4 \mathrm{~kb}$ ) and a small-insert 
library (average insert size $1.4 \mathrm{~kb}$ ) were constructed in pExpress 1 (Not I-Eco RV cloned into T1 phage-resistant DH10B E. coli).

\section{DNA sequencing}

P. marinus TXsc ESTs were obtained using two methods. First, 308 individual recombinant phage were selected randomly and cored out from the LB agar plates into micro-centrifuge tubes containing $400 \mu \mathrm{l}$ of TMG (Trismagnesium-gelatin) buffer and two drops $(\sim 50 \mu \mathrm{l})$ of chloroform. cDNA inserts were amplified with T3 and T7 primers, resolved in a $1.5 \%$ agarose gel $(\mathrm{w} / \mathrm{v})$, recovered using the QIAex II kit (QIAGEN, Valencia, CA), and used for direct sequencing. Second, pBluescriptKS(-) phagemid from the Lambda ZAP vectors was mass excised from both libraries and individual colonies grown for $24 \mathrm{~h}$ in a volume of $3 \mathrm{ml}$ for plasmid preparations. In both cases, single-pass sequencing of the $5^{\prime}$ end of the cDNA clone was carried out to generate the ESTs. $P$. marinus CB5D4 ESTs were sequenced using the M13 primers.

\section{Clustering and assembly of EST/mRNA sequences}

EST sequences were pre-processed to determine the sequence quality and to remove cloning vector sequences from the reads using the Phred and Cross-match software http://www.phrap.org. Poly-A/T tail trimming was done using the 'EMBOSS' Trimmest program [43] before submission to GenBank (accessions \#EH059339 - EH090757; GR954914-GR955219; GR955352-GR955353). Sequence assembly was performed by first clustering the ESTs into groups of similar sequences, using TIGR's TGICL [44]. Subsequently, each cluster was separately assembled into consensus sequences consisting of the longest nonredundant stretch of multiple aligned ESTs, using the CAP4 algorithm (Parcel Inc.; http://www.paracel.com). The sequences that did not cluster were treated as singletons. The cluster consensus and singleton sequences are named Pm00001-Pm07863 and are available in Additional File 1.

\section{Annotation of the P. marinus EST sequences}

Consensus sequences of the EST assemblies and singletons were compared with the NCBI non-redundant (nr) protein database (May 2009) using the BLASTX algorithm and the GenBank dbEST database (May 2009) using the TBLASTX algorithm [45] with the default parameters and with a cut-off E-value $\leq 1 \mathrm{e}-5$. $P$. marinus ESTs were removed from dbEST to avoid self hits during screening. Determination of the taxonomic affinities of hits was based upon an NCBI taxonomic trace-back of best hits. For ease of presentation we have grouped the red and green algae together with the plants, and the brown algae with the Stramenopiles.
The PLAN web system (Personal BLAST Navigator, Noble Foundation) was used to assign functional annotation based on the top BLASTX hit and the gene ontology (GO) sequence database [46]. To identify poorly conserved, or short fragments of genes contained in the ESTs, six-frame translations of the sequences were generated. This resulted in 23,888 open reading frames (ORFs) that are $\geq 75$ amino acids. We searched the ORFs with Pfam (Protein Families Database) (ver. 22.0) with an Evalue threshold of 0.1 to identify protein family domains. Putative signal peptides were identified using SignalP 3.0 server http://www.cbs.dtu.dk/services/SignalP/ and SecretomeP 2.0 server http://www.cbs.dtu.dk/services/

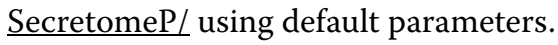

\section{Analysis of orthology}

We used the annotated proteins from 21 genomes [Additional file 2: Supplemental Table S1] from diverse organisms across the tree of life together with the P. marinus proteome (ORF translations of ESTs) to identify orthologs with the OrthoMCL algorithm [47]. The OrthoMCL parameters used for the analysis were: BLASTP E-value > 1e-25 and an inflation parameter of 1.5. Multiple sequence alignment (MSA) was performed on ortholog groups that are shared by $\geq 4$ taxa including P. marinus. MSA was carried out using ClustalW [48] enabling the 'TOSSGAPS' option and using the default values for all other parameters. The regions that contained gaps or were highly divergent were removed from the MSA by GBLOCKS [49] using its default settings. Phylogenetic analysis was performed on the filtered multiple sequence alignments using Seqboot, Protdist, Neighbor and Consense Tree (Phylip) [50], and the nearest neighbor of each $P$. marinus sequence was determined.

\section{Searches for spliced leaders}

The first $22 \mathrm{bp}$ from the 5 ' end of each of the consensus ESTs were extracted and analyzed with the de novo pattern-finding algorithm MEME to identify over-represented patterns. The width for patterns was set at $22 \mathrm{nt}$ and the zoops (zero or one per sequence) mode of occurrence was specified. Patterns that contained similarity or partial similarity to previously identified spliced leader (SL) sequences in dinoflagellates and Perkinsus marinus were examined in further detail. ESTs that contain potential partial SL sequences at the $5^{\prime}$ end were enumerated, and the draft sequence of the $P$. marinus genome (GenBank Project ID: 12736) was searched using regular expressions to find exact SL consensus sequences. Genomic sequence (+/- $200 \mathrm{nt}$ ) flanking each of the putative SL loci was obtained, compared, and used to search the $P$. marinus ESTs. 


\section{Results and Discussion EST sequence analysis}

Large-scale single-pass sequencing of cDNA clones randomly picked from libraries has proven to be a powerful gene discovery approach and represents a "snapshot" of gene expression in a given tissue and/or developmental stage [51,52]. We took advantage of in vitro culture methods for $P$. marinus trophozoites to generate the first EST data set for a member of the Perkinsozoa, a phylum that includes parasites of mollusks and microeukaryotes [11]. Sequencing of the $5^{\prime}$ end of cDNA clones from the two strains of $P$. marinus trophozoites cultured in either standard or oyster serum-supplemented medium resulted in 4 EST libraries. The number of ESTs sequenced for each library is shown in Table 1. Initial clustering using TGICL software (JCVI) divided these sequences into 4,876 clusters. The clusters were then further assembled using CAP4 to produce 5,181 final clusters and 2,682 singletons, yielding a total of 7,863 unique sequences (Pm0001 - Pm07863), or potential unigenes [Additional File 1]. The average cluster length was $1,066 \mathrm{bp}$.

\section{Comparison of ESTs obtained in the presence and absence of oyster serum}

Previously, we have shown that supplementation of the Perkinsus culture medium with plasma from heavily infected C. virginica oysters resulted in a $32 \%$ decrease in proliferation of $P$. marinus; the inhibitory effect is less pronounced with plasma from moderately infected and uninfected oysters [41]. C. virginica plasma can also specifically inhibit protease activity, including from P. marinus. Analysis of the EST sequences from the serumsupplemented library revealed: aldolase, proteases, histone-specific proteins, serine/threonin-protein kinase, deoxycytidylate deaminase and oxidoreductase enzymes, and various transporters [Additional file 2: Supplemental

Table 1: EST sequence numbers by library, Perkinsus strain and sequence source.

\begin{tabular}{|c|c|}
\hline $\begin{array}{l}\text { P. marinus trophozoite } \\
\text { cultures and EST source }\end{array}$ & No. of ESTs \\
\hline $\begin{array}{l}\text { P. marinus CB5D4* (TIGR- } \\
\text { JCVI) }\end{array}$ & 28,882 \\
\hline $\begin{array}{l}\text { P. marinus TXsc (without } \\
\text { serum) (SOM/IMET) }\end{array}$ & 1,243 \\
\hline $\begin{array}{l}\text { P. marinus TXsc (oyster } \\
\text { serum-supplemented) (SOM/ } \\
\text { IMET) }\end{array}$ & 1,602 \\
\hline Total & 31,727 \\
\hline
\end{tabular}

Table S2]. However, a comparison between the ESTs obtained from the standard and oyster serum - supplemented culture (Table 1) is not possible. There are insufficient ESTs for conducting statistically-significant comparisons under the different conditions due to the very small sample size from the serum-supplemented library. Combined sequences from both culture conditions were used for all subsequent analyses.

Similarity searches of the NCBI nr protein database with the $P$. marinus 7,863 unique sequences revealed that 4,325 , (55\%) have significant similarity to proteins in the database with E-value $\leq 1 \mathrm{e}-5$. Figure 1 shows the cumulative distribution of nr BLASTX hits by taxonomic group. The $P$. marinus sequences had the largest number of hits to protein sequences of alveolates followed by hits to proteins of Metazoa/Fungi and Viridiplantae. The Viridiplantae hits may be significant with respect to the relict plastid organelle and are discussed below. Interestingly, there are also a number of hits to viruses. Subsequent the description of $P$. marinus and most other Perkinsus spp., transmission electron microscopy (TEM) studies have shown "virus-like particles" in both the nucleus and in the cytoplasm $[6,53,54]$. Searches of the newly generated Perkinsus genome sequence for viral sequences reveals more than 350 sequences annotated as putative retrovirus polyproteins. Especially interesting is the EER13269 sequence, which encodes a 3,947 aa protein with putative hits to viral related proteins including RNase $\mathrm{H}$, integrases, retroposons, reverse transcriptase, transposase, and arginine methyltransferase-interacting proteins. TBLASTN analysis of the Perkinsus ESTs with EER13269 results in numerous significant hits to clusters: Pm01789, Pm01239, Pm01095, Pm07693, Pm07559, Pm06487, Pm00183, Pm04306, Pm01512, Pm02880 and Pm06668.

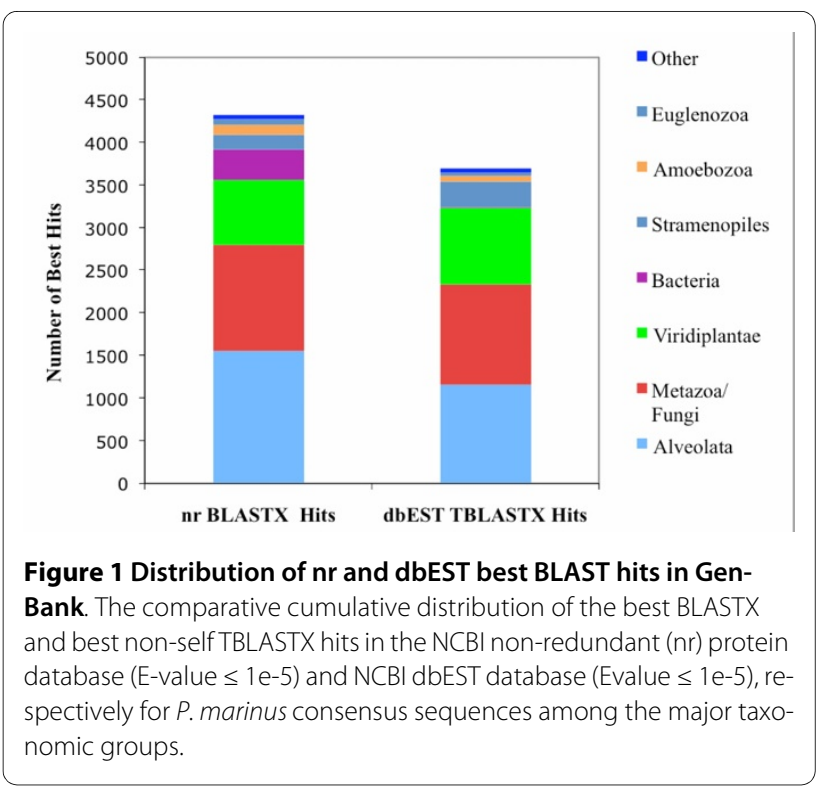


In addition, ESTs Pm00328, Pm01050, Pm04352, Pm06163, Pm07375 and Pm07559 have hits to other viruses including retroviruses. The genome annotation together with EST data provide preliminary evidence for the presence of a virus and/or retrotransposon elements in the Perkinsus genome, a finding with potential implications for Perkinsus biology, tool development, and the development of intervention strategies.

Figure 2 shows the distribution of the most significant hits among the Chromalveolata, a supergroup that encompasses alveolates (dinoflagellates, apicomplexans, ciliates) and related protistan phyla (diatoms, others). Within the chromoalveolates, protein sequences from organisms in the phylum Apicomplexa had the highest number of hits $(1,213)$, although this result is biased by the relative paucity of dinoflagellate sequences in $\mathrm{nr}$ relative to apicomplexan sequences [Additional file 2: Supplemental Table S3]. The Perkinsozoa (Perkinsus, Parvilucifera, and Rastrimonas) are considered the earliest diverging sister group of the dinoflagellates [5,8,55]. Indeed, this phylogenetic position at the base of the dinoflagellate branch makes the Perkinsozoa a key taxon for understanding unique adaptations (e.g. parasitism) within the Alveolata [56]. The similarity of $P$. marinus sequences to various members of these phyla provides important insight into their relevance in alveolate-specific physiology, and helps prioritize them for functional characterization. Even though protein sequences from ciliates are well represented in the $n r$ database [136,531 from 2 ciliate genome sequences as of May, 2009; Additional file 2: Supplemental Table S3], the relatively small number of best hits to ciliates indicates the closer affinity of $P$. marinus to dinoflagellates and apicomplexans than to the ciliates.

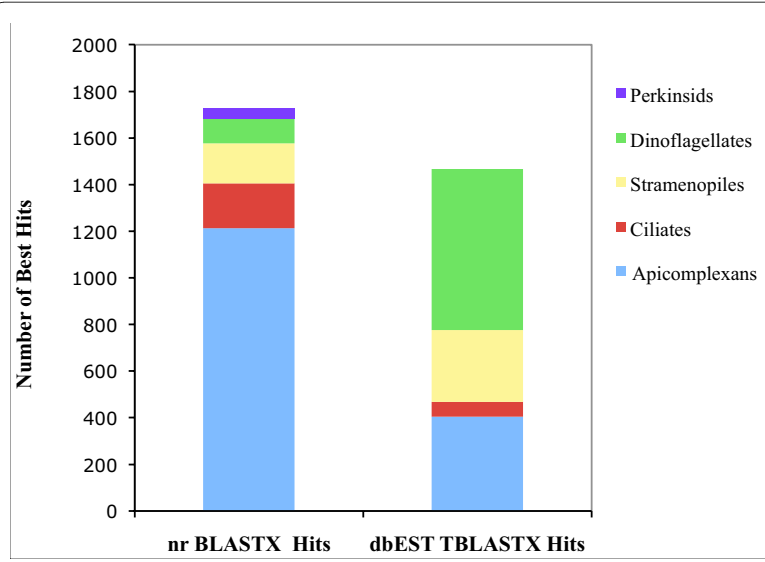

Figure 2 Distribution of $\mathrm{nr}$ and dbEST best BLAST hits among Chromalveolates. The comparative cumulative distribution of the best BLASTX and best non-self TBLASTX hits in the NCBI non-redundant (nr) protein database (E-value $\leq 1 \mathrm{e}-5$ ) and NCBI dbEST database (Evalue $\leq 1 \mathrm{e}-5$ ), respectively for $P$. marinus consensus sequences among the Chromalveolata
EST gene discovery projects for several members of the dinoflagellates including Alexandrium tamarense [57], Alexandrium fundyense [58], Karenia brevis [59], Lingulodinium polyedrum [60,61], Amphidinium carterae [60], and Symbiodinium sp. [52] have been completed. TBLASTX comparisons of all $P$. marinus sequences to the NCBI dbEST database were performed. Figure 1 shows the top hits of the Perkinsus sequences to ESTs from various taxonomic groups. TBLASTX analysis of 7,863 sequences against dbEST resulted in 3,698 top hits (47\%), within which the Alveolata were the most wellrepresented. Among the chromalveolates, dinoflagellates had the maximum number of top hits (690 hits; Figure 2), an observation that supports the existing phylogenetic placement of $P$. marinus closer to the dinoflagellates than to the apicomplexans $[12,13]$.

Molecular phylogenetic data have shown that P. mari$n u s$ is a basal alveolate derived from ancestral dinoflagellates just after the split from apicomplexans [62]. Further evidence indicating a relationship of $P$. marinus to the dinoflagellates was revealed with the discovery of SL trans-splicing in $P$. marinus and $P$. chesapeaki cDNAs [63], an mRNA processing phenomenon found in several dinoflagellate species [64]. Trans-splicing in P. marinus has been reported, but the SL sequence bears a single nucleotide change with respect to the canonical sequence in dinoflagellates [64]. A considerable number (14.7\%), of the $P$. marinus ESTs contain partial SL sequences identical to the reported single-nucleotide non-canonical SL sequence. The longest SL identified was $13 \mathrm{nts}$ and was present in 40 different sequences. Partial SL sequences of $\geq 5$ nt were observed in 1,156 consensus sequences. Incomplete SL sequences in cDNA are common [65] and believed to be the result of inhibitors, often $5^{\prime}$ message modifications, that interfere with reverse transcription. We have identified a putative full-length $22 \mathrm{nt}$ SL in three P. marinus Nramp divalent cation transporters (Lin, Z., Fernández-Robledo, J.A., Cellier, M.F.M. Vasta, G.R., unpublished results). Numerous 22 nt SL sequences are encoded in the $P$. marinus genome (Joseph, S.J., and Kissinger, J.C., unpublished data), and although no fulllength spliced-leader sequences were observed in the ESTs presented here, putative ESTs corresponding to portions of genomic SL loci were identified.

\section{Functional categorization of Perkinsus sequences}

Gene ontology (GO) categories were assigned based on BLASTX hits according to the PLAN web system. Figure 3 shows the distribution of gene ontology terms ( $1^{\text {st }}$ level GO terms) according to the GO consortium. Cellular process $(32.7 \%)$ was the most dominant term out of the 8,670 consensus sequences that were assigned to the Biological Process GO category (Figure 3(a)). This was followed by metabolism at $23.4 \%$. Another $9 \%$ percent 

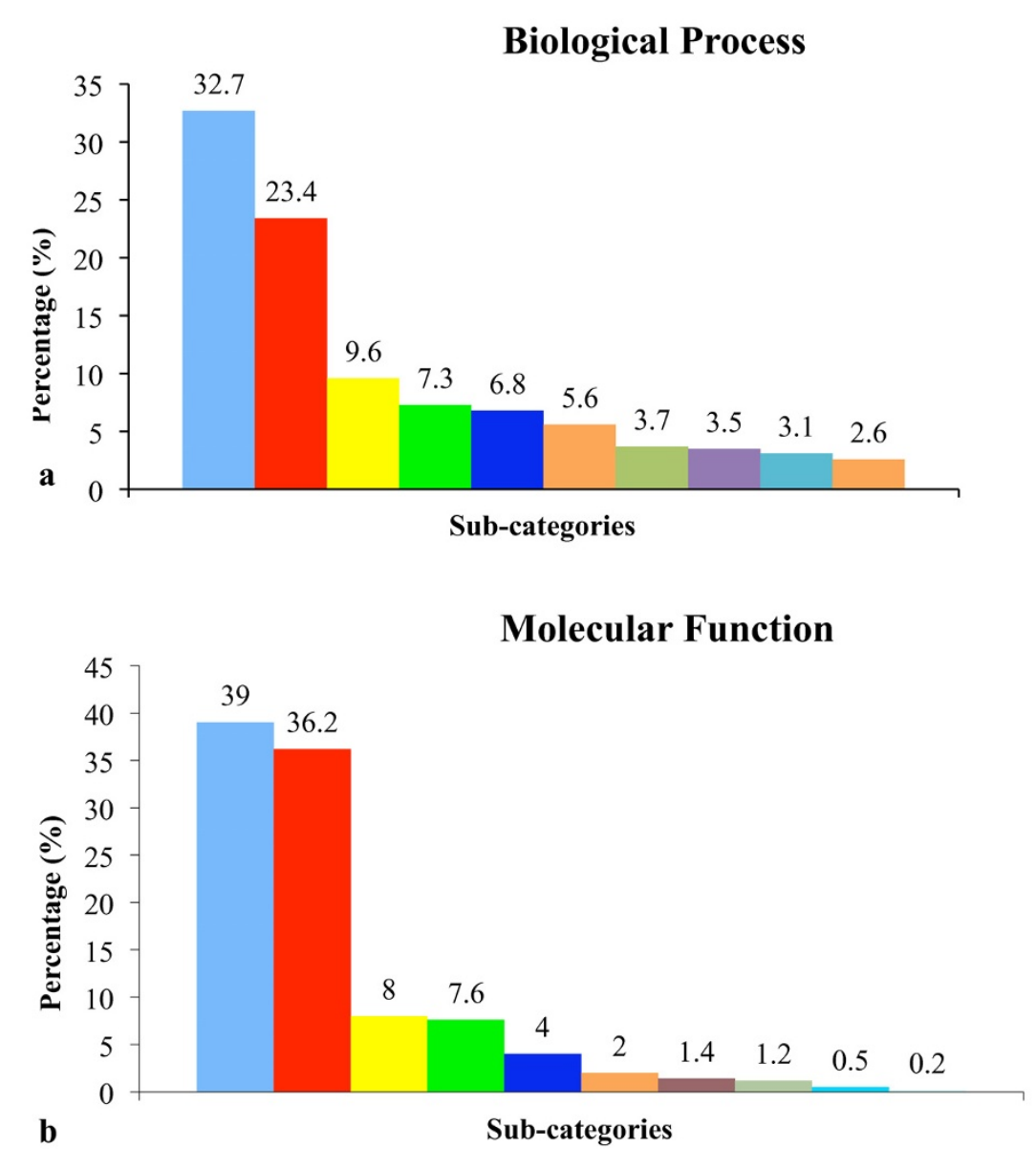

\section{Cellular Component}

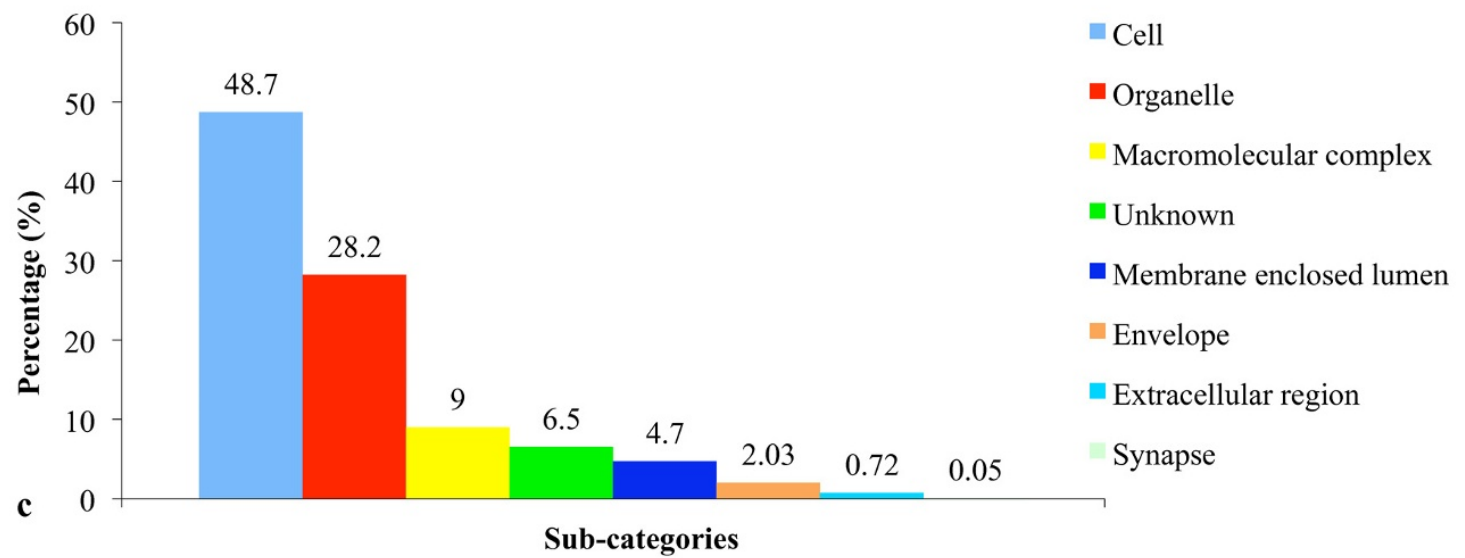

Figure 3 Gene Ontology annotation of $\boldsymbol{P}$. marinus unique sequences. The top BLASTX hit provided annotation and functional categorization (gene ontology assignment) for each $P$. marinus assembled consensus sequences. The total numbers of sequences annotated for each main category are (a) 8,670 for Biological Process, (b) 3,618 for Molecular Function and (c) 5,452 for Cellular Component. A single gene product may be associated with multiple $\mathrm{GO}$ annotations with in a single category, giving rise to more $\mathrm{GO}$ annotations than sequences.
Catalytic activity

- Binding

Transporter

Unknown

- Structural molecular activity

- Transcription regulator activity

Enzyme regulatory activity

- Translation regulator activity

- Molecular Transducer activity Antioxidant

Cellular

Multicellular organism process

- Biological regulation

Localization

- Stimulus response

Biological process unknown

Reproduction

Growth
Metabolic 
represented parasite-specific 'developmental' sub-categories. Approximately $7 \%$ of the terms were for regulation of protein biosynthesis, transcription, cell proliferation, apoptosis, DNA replication, and glycolysis. Significant representation of proteins involved in translation has also been reported in EST sequencing projects for Toxoplasma tachyzoites [35,66], Cryptosporidium sporozoites [67] and Eimeria merozoites [68]. Abundant messages for ribosomal proteins are suggestive of the rapid and extensive protein translation that accompanies parasite differentiation and multiplication following host-cell invasion. Catalytic activity (39\%) was the most dominant molecular function (Figure 3(b)). Multiple proteases, including cathepsins $\mathrm{B}, \mathrm{E}, \mathrm{H}, \mathrm{L}$, and $\mathrm{S}$, and serine-type peptidase, were identified. The expression of multiple proteases in $P$. marinus may indicate their role(s) in processing the host protein substrates to facilitate uptake of their metabolic products to sustain normal cell function and proliferation. The expression of superoxide dismutase (SOD) was consistent with prior reports. $P$. marinus uses SODs to protect itself from reactive oxygen intermediates (ROIs) generated by the host's oxidative enzymes [69-74]. Sequences identified as 'binding' components comprised about $36 \%$ of the total, followed by 'transporter' at $8 \%$, the majority being ion transporters and transporters with carrier activity. Some of the 'transporter' consensus sequences fell into the 'ATPase coupled transporter' subcategory, which includes transporters of sugars, peptides, amino acids, and other small molecules. Around 2\% were designated as transcriptional regulators, with the majority designated as having transcription factor activity. Over two-thirds of the consensus sequences were localized by cellular component to either cell or organelle, as shown in Figure 3(c). Of this, the majority was assigned to the nucleus, mitochondrion, endoplasmic reticulum, nucleolus, and a few were assigned to chloroplast thylakoid. Other sequences (4.7\%) were categorized as 'membrane enclosed lumen', and included mitochondrial, nucleolar, and cytosolic membranes.

\section{Functional analysis of protein sequences}

We analyzed conserved protein domains using Pfam as a database to predict the function of ORFs generated from $P$. marinus consensus sequences. Overall, 2,704 ORFs encode protein domains similar to 1,042 Pfam protein families (E-value < 0.1). Among these Pfam families, 65 families were denoted as DUFs (Domain of Unknown Function). We found that 2,009 ORFs contain a single PFAM protein domain while 492 have two domains, 96 have three, 58 have four, 28 have five and 28 ORFs contain six or more domains. The most abundant Pfam domains in $P$. marinus are presented in Table 2; protein domains that are of evolutionary and therapeutic interest in this parasite are shown in Table 3.

\section{Orthologous groups}

To determine the number of potential orthologs between P. marinus and proteins from 21 organisms representative of the major divisions of the tree of life, [Additional file 2: Supplemental Table S1] we performed a clustering analysis on the non-redundant 21 genome protein sets along with the $P$. marinus EST ORF proteome using the OrthoMCL program [47]. In brief, OrthoMCL defines clusters based on reciprocal best BLASTP hits and sorts proteins without a reciprocal best BLASTP hit into the best matching cluster. The input dataset for OrthoMCL consisted of 325,188 protein sequences from 22 proteomes. $P$. marinus sequences $(5,661$ ORFs) were found in 2,878 ortholog groups, of which 1,715 are unique to $P$. marinus i.e., no sequences from other taxa are present in this group. The extent to which $P$. marinus shares orthologous genes with the 21 other taxa examined is listed in Additional file 2: Supplemental Table S4. As the number of taxa increases, the number of shared genes decreases.

\section{Phylogenetic analysis}

Automated phylogenetic analyses of the orthologous clusters was performed to determine the nearest taxonomic neighbor for each sequence. This approach is useful for establishing gene origins, identifying genes with restricted phylogenetic distribution and to identify putative horizontal gene transfer (HGT) events in the P. marinus genome. Phylogenetic trees were constructed from the 1,042, ortholog groups that shared $\geq 4$ taxa including P. marinus [Additional file 2: Supplemental Table S4]. Multiple alignments were created with ClustalW and filtered using GBLOCKS to remove ambiguous regions. Only ortholog groups with $\geq 50$ aligned aa were used for phylogenetic analysis, and 291 alignments met this criterion. Neighbor-joining trees were constructed with bootstrap support to determine the $P$. marinus nearest neighbor. Not surprisingly, $54 \%$ of the orthologous groups have alveolates as the closest neighbor to $P$. marinus (48\% apicomplexans and 6\% ciliates (dinoflagellates are not represented)). Toxoplasma gondii was the most highly represented species. $P$. marinus sequences also show nearest neighbors of kinetoplastids, bacteria, archaea and red algae. For the gene encoding 2-C-methylD-erythritol 4-phosphate cytidyly transferase (IspD), one of the seven enzymes involved in plastid metabolism recently discovered in $P$. marinus [75-77] its nearest neighbor is that from the red algae Cyanidioschyzon merolae. Other important taxonomic groups that were found to be closest neighbors to $P$. marinus include the Heterokontophyta [Thalassiosira pseudonana (17 genes), and Phytopthora ramorum (36 genes)], Plantae [Arabidopsis thaliana (26 genes)], Animalia [Homo sapiens (24 genes), Drosophila melanogaster (7 genes)], and Fungi [Saccharomyces cerevisiae (11 genes)]. It should be noted 
Table 2: The 20 most common Pfam domains

\begin{tabular}{|c|c|c|}
\hline Description of Pfam domain & Pfam accession & No. of P. marinus ORFs \\
\hline $\begin{array}{l}\text { Transmembrane amino acid transporter } \\
\text { protein }\end{array}$ & PF01490 & 27 \\
\hline$A B C$ transporter & PF00005 & 26 \\
\hline ADP-ribosylation factor family & PF00025 & 30 \\
\hline Helicase conserved C-terminal domain & PF00271 & 23 \\
\hline Mitochondrial carrier protein & PF00153 & 22 \\
\hline Papain family cysteine peptidase & PF00112 & 11 \\
\hline Protein kinase domain & PF00069 & 51 \\
\hline Proteasome A-type and B-type & PF00227 & 20 \\
\hline RNA recognition motif 1 & PF00076 & 78 \\
\hline RNA recognition motif 2 & PF04059 & 18 \\
\hline Sugar (and other) transporter & PF00083 & 15 \\
\hline Tetra tricopeptide repeat & PF00515 & 20 \\
\hline tRNA synthetase & PF00133 & 11 \\
\hline WD domain, G-beta repeat & PF00400 & 36 \\
\hline Zinc finger $\mathrm{C} 3 \mathrm{HC} 4$ type & PF00097 & 77 \\
\hline Zinc finger $\mathrm{C} 8 \mathrm{C} 5 \mathrm{C} 3 \mathrm{H}$ type & PF00642 & 43 \\
\hline $\begin{array}{l}\text { ATPase family associated with various } \\
\text { cellular activities }\end{array}$ & PF00004 & 16 \\
\hline DEAD/DEAH box helicase & PF00270 & 12 \\
\hline $\begin{array}{l}\text { Dna J domain: associated with hsp } 70 \text { heat- } \\
\text { shock protein }\end{array}$ & PF00226 & 35 \\
\hline $\begin{array}{l}\text { Cytochrome b5-like Heme/Steroid binding } \\
\text { domain }\end{array}$ & PF00173 & 12 \\
\hline
\end{tabular}

that the nearest neighbors are expected to change as more taxa are sequenced and added to the analysis.

\section{Sequences of particular interest Proteases}

The presence of protease sequences in $P$. marinus deserves special mention. Proteases from Perkinsus are involved in pathogenesis and host-parasite interactions; indeed, oyster homogenate enhances the infectivity of the parasite and reflects changes in the Perkinsus extracellular product (ECP) composition [78]. In vitro protease expression and cellular differentiation also appear to be modulated by oyster tissue extracts; fewer proteases can be observed in Crassostrea ariakensis supplemented medium compared to C. virginica supplemented medium [79]. There is also evidence that oyster plasma protease inhibitor contributes to some oyster species' resistance to Perkinsus [80-82]. Although several proteases have already been reported in $P$. marinus $[21,83]$ our EST analysis identified numerous $P$. marinus sequences with Pfam domains (Table 3) and strong BLAST similarity (Table 4) to cathepsin-like cysteine protease, subtilisin-like serine protease, rhomboid-like protease 1, cysteine protease, ATP-dependent protease, serine protease, metacaspase 1 precursor, and ubiquitin-specific proteases. As observed for other well-characterized parasites, some proteases produced by $P$. marinus might degrade host protein substrates to acquire the nutrients necessary for normal cell function and proliferation. Interestingly, several of the ESTs encoded proteases with possible signal/secretion peptides, including subtilisin-like serine protease (score 0.882 ), cathepsin-like cysteine protease (score 0.861), calcium-dependent cysteine protease (score 0.782) and metacaspase 1 precursor (score 0.923). Congruent with the hypothesis that the oyster host has adaptations to contend with parasite peptidases, C. virginica plasma contains a serine protease inhibitor that binds tightly to subtilisin and perkinsin was purified from the plasma of C. virginica suggesting a role in host defense against the parasite's proteolytic activity [84].

Antioxidant enzymes

Upon phagocytosis by oyster hemocytes, Perkinsus marinus trophozites localize inside phagosome-like structures where they remain viable and undergo proliferation. 
Table 3: Pfam domains of interest identified in P. marinus EST cluster open reading frames.

\begin{tabular}{|c|c|c|c|}
\hline Pfam family domain & Description of the domain & Pfam accession & P. marinus Cluster IDs \\
\hline \multicolumn{4}{|l|}{ Protease } \\
\hline Peptidase_C1 & $\begin{array}{l}\text { Papain family cysteine } \\
\text { protease }\end{array}$ & PF00112 & $\begin{array}{l}\text { Pm02598, Pm05550, } \\
\text { Pm02598, Pm01528, } \\
\text { Pm00748, Pm00174, } \\
\text { Pm00175, Pm00188, } \\
\text { Pm01093, Pm02540, Pm00187 }\end{array}$ \\
\hline Peptidase_C13 & Asparaginyl peptidase & PF01650 & Pm03639 \\
\hline Peptidase_C14 & Caspase & PF00656 & Pm00713 \\
\hline Peptidase_C15 & Pyroglutamyl peptidase & PF01470 & Pm03835 \\
\hline Peptidase_C26 & Gamma-glutamyl hydrolase & PF07722 & Pm03998, Pm00516, Pm01387 \\
\hline Peptidase_C48 & $\begin{array}{l}\text { Ulp1 protease family, C- } \\
\text { terminal catalytic domain }\end{array}$ & PF02902 & Pm03070 \\
\hline Peptidase_C54 & Peptidase family C54 & PF03416 & Pm01837 \\
\hline Peptidase_C69 & Peptidase family C69 & PF03577 & $\begin{array}{l}\text { Pm00327, Pm01089, } \\
\text { Pm00100, Pm00136 }\end{array}$ \\
\hline Peptidase_M1 & Peptidase family M1 & PF01433 & Pm04612 \\
\hline Peptidase_M14 & Zinc carboxy peptidase & PF00246 & Pm04493 \\
\hline Peptidase_M16 & Insulinase & PF00675 & $\begin{array}{l}\text { Pm05750, Pm04910, } \\
\text { Pm01740, Pm00611, } \\
\text { Pm01740, Pm07103 }\end{array}$ \\
\hline Peptidase_M17 & Cytosol amino peptidase & PF00883 & Pm05788, Pm04421 \\
\hline Peptidase_M18 & $\begin{array}{l}\text { Aminopeptidase I zinc } \\
\text { metalloprotease }\end{array}$ & PF02127 & Pm00540 \\
\hline Peptidase_M20 & Peptidase family M20 & PF01546 & Pm05166 \\
\hline Peptidase_M24 & Metallopeptidase family M24 & PF00557 & $\begin{array}{l}\text { Pm00721, Pm05108, } \\
\text { Pm01923, Pm01484, } \\
\text { Pm03328, Pm05608, Pm01369 }\end{array}$ \\
\hline Peptidase_M3 & Peptidase family M3 & PF01432 & Pm06832 \\
\hline Peptidase_M41 & Peptidase family M41 & PF01432 & Pm06918 \\
\hline Peptidase_M48 & Peptidase family M48 & PF01435 & Pm02186 \\
\hline Peptidase_S10 & Serine carboxy peptidase & PF00450 & $\begin{array}{l}\text { Pm04952, Pm03877, } \\
\text { Pm07791, Pm01720, } \\
\text { Pm07092, Pm05386, } \\
\text { Pm02482, Pm07066, } \\
\text { Pm02294, Pm00207, } \\
\text { Pm00346, Pm06037 }\end{array}$ \\
\hline Peptidase_S15 & X-Pro dipeptidyl peptidase & PF02129 & Pm01961 \\
\hline Peptidase_S24 & Peptidase S24 like & PF00717 & Pm02936, Pm07617 \\
\hline Peptidase_S8 & Subtilase family & PF00082 & $\begin{array}{l}\text { Pm05197, Pm00155, } \\
\text { Pm01368, Pm00344, } \\
\text { Pm00265, Pm02193, } \\
\text { Pm03660, Pm00235, Pm00154 }\end{array}$ \\
\hline Peptidase_S9 & Prolyl oligo peptidase family & PF00326 & Pm01915 \\
\hline Rhomboid & Rhomboid-like family & PF01694 & Pm05706, Pm00872 \\
\hline
\end{tabular}


Table 3: Pfam domains of interest identified in P. marinus EST cluster open reading frames. (Continued)

\begin{tabular}{|c|c|c|c|}
\hline \multicolumn{4}{|c|}{ Oxidative Enzymes } \\
\hline Sod_Fe_N & $\begin{array}{l}\text { Iron/manganese superoxide } \\
\text { dismutase, alpha-hairpin }\end{array}$ & PF00081 & Pm00420, Pm05057, Pm02278 \\
\hline Sod_Fe_C & $\begin{array}{l}\text { Iron/manganese superoxide } \\
\text { dismutase, C-terminal domain }\end{array}$ & PF02777 & Pm00420, Pm05057, Pm02278 \\
\hline Glutaredoxin & Glutaredoxin & PF00462 & $\begin{array}{l}\text { Pm07679, Pm07604, } \\
\text { Pm04790, Pm04765 }\end{array}$ \\
\hline Thioredoxin & Thioredoxin & PF00085 & $\begin{array}{l}\text { Pm01390, Pm02808, } \\
\text { Pm00345, Pm02770, } \\
\text { Pm07686, Pm03543, } \\
\text { Pm01102, Pm00367, } \\
\text { Pm03381, Pm01163, } \\
\text { Pm03631, Pm07411, } \\
\text { Pm02203, Pm03850, Pm05817 }\end{array}$ \\
\hline \multicolumn{4}{|c|}{ Fatty Acid Synthesis } \\
\hline FA_desaturase & Fatty acid desaturase & PF00487 & $\begin{array}{l}\text { Pm02182, Pm03006, } \\
\text { Pm06024, Pm07340, } \\
\text { Pm02313, Pm02648, } \\
\text { Pm03710, Pm03609 }\end{array}$ \\
\hline \multicolumn{4}{|c|}{ Isoprenoid Pathway } \\
\hline IspD & MEP cytidylyl transferase & PF01128 & Pm05015 \\
\hline \multicolumn{4}{|c|}{ Glycosyl transferase Family } \\
\hline Glyco_transf_20 & $\begin{array}{l}\text { Trehalose-6-phosphate } \\
\text { transferase }\end{array}$ & PF00982 & Pm01181 \\
\hline Glyco_transf_22 & $\begin{array}{l}\text { Alg9-like mannosyl } \\
\text { transferase }\end{array}$ & PF03901 & Pm03101 \\
\hline Glyco_transf_28 & $\begin{array}{l}\text { UDP-N-acetylglucosamine } \\
\text { transferase }\end{array}$ & PF03033 & Pm01717 \\
\hline Glyco_transf_8 & $\begin{array}{l}\text { Lipopolysaccharide galactosyl } \\
\text { tranferase }\end{array}$ & PF01501 & Pm01991 \\
\hline Alg14 & $\begin{array}{l}\text { Oligosaccharide biosynthesis } \\
\text { protein Alg14-like }\end{array}$ & PF08660 & Pm04341 \\
\hline
\end{tabular}

\section{Heat Shock Proteins}

\begin{tabular}{|c|c|c|c|}
\hline HSP90 & Heat shock protein 90 & PF00183 & $\begin{array}{l}\text { Pm00142, Pm00170, } \\
\text { Pm00836, Pm03154 }\end{array}$ \\
\hline HSP70 & Heat shock protein 70 & PF00012 & $\begin{array}{l}\text { Pm00172, Pm05287, } \\
\text { Pm00172, Pm03153, } \\
\text { Pm05233, Pm06933, } \\
\text { Pm00065, Pm00137, } \\
\text { Pm01460, Pm00363, Pm01884 }\end{array}$ \\
\hline
\end{tabular}


Table 3: Pfam domains of interest identified in P. marinus EST cluster open reading frames. (Continued)

\begin{tabular}{|c|c|c|c|}
\hline Cpn60_TCP1 & $\begin{array}{l}\text { HSp60 chaperonin family and } \\
\text { the TCP- } 1 \text { family }\end{array}$ & PF00118 & $\begin{array}{l}\text { Pm03177, Pm02627, } \\
\text { Pm01137, Pm02465, } \\
\text { Pm00825, Pm03422, } \\
\text { Pm04033, Pm02165, } \\
\text { Pm01657, Pm05905 }\end{array}$ \\
\hline \multicolumn{4}{|l|}{ Lectins } \\
\hline Ricin_B_lectin & Ricin-type beta-trefoil domain & PF00652 & Pm01439, Pm02264, Pm03133 \\
\hline Lectin_leg_like & Legume -like lectin family & PF03388 & Pm03024, Pm03327 \\
\hline \multicolumn{4}{|l|}{ Nucleotide Metabolism } \\
\hline \multirow[t]{2}{*}{ Pribosyltran Adenylsucc_synt } & $\begin{array}{l}\text { Phosphoribosyl transferase } \\
\text { adenylosuccinate synthetase }\end{array}$ & PF00156 & Pm04986, Pm07718, Pm03005 \\
\hline & & PF00709 & Pm02370 \\
\hline
\end{tabular}

Available evidence indicates that the parasite survives oxidative stress imposed by the oyster defense mechanisms [30,31]. Protistan parasites generally contain antioxidant activities, but may lack other enzymes typical of animal antioxidant pathways. During recent years we identified and characterized in $P$. marinus trophozites iron SOD and ascorbate-dependent peroxidase (APX) that degrade the ROIs resulting from the oxidative burst associated with phagocytosis [73,74]. Specifically, $P$. marinus SOD1 (PmSOD1) encodes a mitochondrial FeSOD [69-74], which may contribute to $P$. marinus resistance to exogenous oxidative damage in host phagocytes [73]. In contrast, although the product of PmSOD2 is predicted to be targeted to a putative plastid, confocal and immunogold studies localized it to the cell periphery and cytoplasmic single membrane compartments [85], raising interesting questions regarding its organellar targeting and the nature of a putative relict plastid described in other Perkinsus species. SOD catalyzes the dismutation of $\mathrm{O}_{2}{ }^{-}$to $\mathrm{H}_{2} \mathrm{O}_{2}$, which may be eliminated by either catalase or peroxidases such as glutathione-dependent peroxidase (GPX). GPX requires reduced glutathione produced by glutathione reductase. Analysis of $P$. marinus ESTs identified sequences for several $P$. marinus oxidative pathway components that are expressed in the trophozoite stage. These include peroxiredoxin 6 , peroxiredoxin $\mathrm{V}$, thioredoxins, glutaredoxins, glutathione reductase, and thioredoxin reductase (Table 5). Sequences highly similar to PmSOD1 and PmSOD2 were identified (Table 5) as well as several confirmatory Pfam domains (Table 3). Because no catalase activity has been detected in $P$. mari$n u s$, and no catalase gene has been identified in its genome, it is likely that some of the abovementioned peroxidases are involved in $\mathrm{H}_{2} \mathrm{O}_{2}$ detoxification.

\section{Fatty acid synthesis}

Lipid analysis of 7 day-old in vitro cultured $P$. marinus trophozoites indicated that triacylglycerol represents $48.7 \%$ of the total lipids [86]. P. marinus trophozoites utilize ${ }_{13} \mathrm{C}$-acetate to synthesize a range of saturated and unsaturated fatty acids and the parasite's ability to synthesize 20:4(n-6) de novo is unique within parasitic protozoa [87]. Eukaryotes employ either the delta- 6 or delta- 8 desaturase pathway, or both, to synthesize arachidonic acid, an essential fatty acid. The meront stage of $P$. marinus synthesizes arachidonic acid through the delta- 8 pathway [88]. In addition, it has been suggested that $P$. marinus cannot synthesize sterols and must sequester them from its host. Perkinsus cells are able to proliferate in complete lipid supplement medium (cod liver oil, cholesterol and alpha tocopherol acetate in detergent) and media containing cholesterol or cholesterol+alpha tocopherol acetate, but fail to proliferate in control medium and medium containing just alpha tocopherol acetate [89]. However, the genome of $P$. marinus encodes 6 out of 7 methylerythrithol phosphate (MEP) pathway genes [75-77] indicating that Perkinsus is able to synthesize de novo sterols (see below: isoprenoid metabolism). ESTs matching enzymes involved in sterol metabolism also include sterol glucosyltransferases (Pm04113, E = 1e47; Pm01717, E = 4e-42; Pm04859, E = 6e-44), sterol C-24 reductase $(\mathrm{Pm} 01729, \mathrm{E}=3 \mathrm{e}-50)$, and sterol desaturase (Pm00771, E = 9e-23). Three $P$. marinus genes encoding the enzymes responsible for arachidonic acid biosynthesis (C18 delta-9-elongating activity, C20 delta-8 desaturase, C20 delta-5 desaturase) are clustered and cotranscribed as an operon [27]. Sequences highly similar to delta-9 desaturase $($ Pm03609, E-value $=1 \mathrm{e}-66)$, delta-8 fatty acid desaturase $(\operatorname{Pm07340,E-value~}=1 \mathrm{e}-161)$, and 


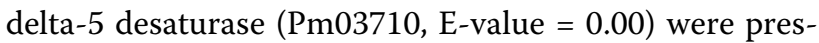
ent, while no sequences similar to delta- 6 fatty acid desaturase were identified, in agreement with the abovementioned observations. Pfam analysis identified 8 fatty acid desaturase domains including the above sequences (Table 3 ).

Sequences similar to the plastid-localized enzyme, acetyl-CoA carboxylase (Pm00609 (E-value = 2e-41) and Pm05907 (E-value = 3e-16) ) involved in fatty acid biosynthesis were also identified in this study. Indeed, it has been shown that Perkinsus proliferation is inhibited by Triclosan and cerulenin, which has been interpreted as evidence for the presence of a plastidic FAS II pathway $[24,25]$. However, when considering the effect of Triclosan as indicative of the relevance of the apicoplast FASII biosynthesis, results should be interpreted with caution, since in Plasmodium, the antimalarial activity of Triclosan is not targeted to FabI [90]. Further, although Theileria is also susceptible to this drug, genes coding for FASII are lacking in the Theileria genome [91].

\section{Heat shock proteins}

Expression of heat shock protein 70 (HSP70) in P. marinus suggests that the parasite might use general stress response genes to overcome the stress imposed by the host environment. In Toxoplasma, the HSP70 gene is expressed during the transition from the active to latent form [92]. In virulent Toxoplasma strains, HSP70 contains seven amino acids not present in the HSP70 from non-virulent strains, and HSP70 expression is elevated 2fold in virulent versus non-virulent strains [93]. A highly similar consensus sequence to the $T$. gondii HSP70 protein $($ Pm00065, Evalue $=0.00)$ was identified in the $P$. marinus EST analysis. Further, two sequences similar to HSP90 were identified, Pm00171 (E-value $=1 \mathrm{e}-176)$ and Pm05367 (E-value $=3 e-60)$. Many heat shock proteins are chaperonins, which function in concert with proteins similar to the delta subunit of the t-complex family of chaperonins, and are found in virtually all organisms including Leishmania [94]. In different species, t-complex chaperonins are involved in protein folding after stressrelated denaturation. Two chaperonin homologs, encoded by Pm03177 and Pm01657, are similar to proteins with roles in thermo-tolerance, cell-cycle progression and hematopoeisis. Pfam analysis detected the same HSP90 and HSP70 proteins as well as and Cpn_TCP1 (HSP60 chaperonin family-TCP-1 family) domains (Table $3)$.

\section{Isoprenoid metabolism}

Although TEM observations have failed to identify a plastid in Perkinsus species [6,95], recent studies suggest that genes associated with secondary plastids may be present. P. marinus possesses genes for a plant-type ferredoxin system that possibly encodes plastid-targeting signals [25]. Recently, TEM observations in Perkinsus olseni revealed a very large (about 375-800 $\mathrm{nm}$ in diameter/ larger axis) organelle with four membranes [26], although concerns have been raised about the nature of the structures observed [85]. Ferredoxin and ferredoxin-NADP reductase, proteins predicted to target the putative relict plastid [25], were identified in our analysis (Table 6). The search for $P$. marinus methylerythrithol phosphate (MEP) pathway genes, responsible for de novo isoprenoid synthesis in plastids, has resulted in the full-length sequences for 6 out of 7 of these genes [75-77]. These provide evidence for a complete MEP pathway in $P$. marinus, and are indicative of a plastid organelle [76]. Four enzymes of the MEP pathway were identified in the present EST study. 1-deoxy-D-xylulose 5-phosphate synthase (DXP synthase) is responsible for conversion of pyruvate and glyceraldehyde 3-phosphate into DXP (Table 6). Another enzyme that functions as an intermediate step in the MEP pathway called MEP cytidylyltransferase (IspD) was also detected in this EST analysis (Pm05015, E-value $=4 \mathrm{e}-26$ ) as was 2C-methyl-D-erythritol 2,4-cyclodiphosphate synthase (ME-CPP synthase) and 4-hydroxy-2methyl-2-butenyl 4-diphosphate synthase (HMBPP synthase). An IspD Pfam domain was identified in one of the above $P$. marinus EST ORFs (Table 3 ).

\section{Glycan assembly and carbohydrate-binding proteins}

Oligosaccharides on cell surface and intracellular glycoconjugates are assembled by the combined activity of glycosyltransferases and glycosidases, and may interact with carbohydrate-binding proteins (lectins). Further, proteincarbohydrate recognition plays a key role in intracellular processes such as protein folding and transport, as well as interactions between cells or cells and the extracellular matrix in functions related to development, immune responses, and host-parasite interactions. It is widely accepted that recognition of parasitic surface glycoconjugates by host humoral or cell-associated lectins are frequently involved in cellular recognition and colonization of the host. Several studies have partially characterized multiple lectins in the oyster plasma and hemocytes, which recognize glycoproteins that display terminal galactose and N-acetylated sugars [96,97]. Flow cytometry analysis of $P$. marinus trophozoites labeled with commercial lectins [98] enabled a tentative identification of some of the sugars present on the surface of the P. marinus trophozoites. Recently, we demonstrated that an oyster galectin present on the hemocyte surface functions as a parasite receptor and facilitates host entry [28]. Once inside the host, trophozoites survive intra-hemocytic killing mechanisms and proliferate [32]. The P. marinus ESTs include several with high similarity to glycosyltransferases and other members of the 'sugar moiety' transferase enzyme family. Four sequences (Pm01326 (E-value = 2e-49), Pm02039 (E-value = 9e-31), Pm07403 (E-value $=1 \mathrm{e}-08)$, Pm02460, E-value $=3 \mathrm{e}-09$ ) show high similarity 
Table 4: P. marinus consensus sequences with similarity to known proteases.

\begin{tabular}{|c|c|c|c|c|}
\hline Protein & $\begin{array}{l}\text { P. marinus EST } \\
\text { cluster ID }\end{array}$ & $\begin{array}{l}\text { GenBank best hit } \\
\text { accession }\end{array}$ & E-value & Species with best hit \\
\hline \multirow{9}{*}{$\begin{array}{l}\text { Subtilisin-like serine } \\
\text { protease }\end{array}$} & Pm00235 & $\underline{\mathrm{AAQ} 54740}$ & 0.00 & Perkinsus marinus \\
\hline & Pm02193 & $\underline{\mathrm{AAQ} 54740}$ & $1 e-119$ & Perkinsus marinus \\
\hline & Pm00154 & $\underline{\mathrm{AAQ} 54740}$ & $7 e-92$ & Perkinsus marinus \\
\hline & Pm01368 & $\underline{\mathrm{AAQ} 54740}$ & $5 e-86$ & Perkinsus marinus \\
\hline & Pm02998 & $\underline{A A Q 54740}$ & $5 e-41$ & Perkinsus marinus \\
\hline & Pm00155 & $\underline{\mathrm{AAQ} 54740}$ & $2 e-37$ & Perkinsus marinus \\
\hline & Pm05826 & $\underline{\mathrm{AAQ} 54740}$ & $3 e-35$ & Perkinsus marinus \\
\hline & Pm06080 & $\underline{\mathrm{AAQ} 54740}$ & $2 e-32$ & Perkinsus marinus \\
\hline & Pm07074 & $\underline{\text { AAQ54740 }}$ & $5 e-18$ & Perkinsus marinus \\
\hline $\begin{array}{l}\text { Cathepsin-likecysteine } \\
\text { protease }\end{array}$ & Pm05181 & $\underline{\text { AAY53767 }}$ & $1 e-55$ & Phytophthora infestans \\
\hline \multirow[t]{4}{*}{$\begin{array}{l}\text { Papain cysteine } \\
\text { protease }\end{array}$} & Pm02690 & $\underline{X P \quad 001012227}$ & $6 e-50$ & $\begin{array}{l}\text { Tetrahymena } \\
\text { thermophila }\end{array}$ \\
\hline & Pm00748 & $\underline{X P \quad 001012227}$ & $2 e-44$ & $\begin{array}{l}\text { Tetrahymena } \\
\text { thermophila }\end{array}$ \\
\hline & Pm02540 & $\underline{X P \quad 001012227}$ & $7 e-36$ & $\begin{array}{l}\text { Tetrahymena } \\
\text { thermophila }\end{array}$ \\
\hline & Pm03675 & $\underline{X P \quad 002295071}$ & $2 e-20$ & $\begin{array}{l}\text { Thalassiosira } \\
\text { pseudonana }\end{array}$ \\
\hline $\begin{array}{l}\text { Rhomboid-like } \\
\text { protease } 1\end{array}$ & Pm05706 & $\underline{\mathrm{Q} 695 \mathrm{U} 0}$ & $3 e-25$ & Toxoplasma gondii \\
\hline Cysteine protease & Pm05710 & $\underline{B A C 75925}$ & $2 e-30$ & Saprolegnia parasitica \\
\hline $\begin{array}{l}\text { Calcium-dependent } \\
\text { cysteine protease, } \\
\text { putative }\end{array}$ & Pm03124 & $\underline{\mathrm{EEC} 03794}$ & $2 \mathrm{e}-19$ & Ixodes scapularis \\
\hline $\begin{array}{l}\text { ATP-dependent } \\
\text { protease La }\end{array}$ & Pm01082 & ZP 01906531 & $1 e-108$ & Plesiocystis pacifica \\
\hline \multirow[t]{2}{*}{$\begin{array}{l}\text { Serine protease, } \\
\text { putative }\end{array}$} & Pm03660 & YP 002603888 & $6 e-28$ & $\begin{array}{l}\text { Desulfobacterium } \\
\text { autotrophicum }\end{array}$ \\
\hline & Pm00265 & YP 002603888 & $2 e-22$ & $\begin{array}{l}\text { Desulfobacterium } \\
\text { autotrophicum }\end{array}$ \\
\hline $\begin{array}{l}\text { Ubiquitin-specific } \\
\text { protease }\end{array}$ & Pm04052 & $\underline{B A D 08755}$ & $5 e-12$ & Oryza sativa \\
\hline
\end{tabular}


Table 4: P. marinus consensus sequences with similarity to known proteases. (Continued)

\begin{tabular}{lllll}
\hline $\begin{array}{l}\text { Metacaspase 1 } \\
\text { precursor, putative }\end{array}$ & Pm00713 & EEB00690 & $6 \mathrm{e}-46$ & Toxoplasmagondii \\
\cline { 2 - 4 } & Pm00714 & $\underline{\text { EEB00690 }}$ & 2e-16 & Toxoplasma gondii \\
\hline Putative LON protease & Pm07114 & AAY58903 & $3 \mathrm{e}-14$ & $\begin{array}{l}\text { Hyaloperonospora } \\
\text { parasitica }\end{array}$ \\
$\begin{array}{l}\text { Peptidase family M48 } \\
\text { domain }\end{array}$ & Pm02186 & EEB02807 & $1 \mathrm{e}-69$ & Toxoplasmagondii \\
\hline
\end{tabular}

to the genes that encode glycosyltransferase in Cryptosporidium hominis and Verrucomicrobium spinosum. BlastX hits to $\mathrm{N}$-acetylglucosaminyltransferase $(\mathrm{Pm} 07672, \quad \mathrm{E}$-value $=4 \mathrm{e}-18)$, mannosyltransferase $($ Pm03101, E-value $=6 \mathrm{e}-36)$, sterol-glucosyltransferase $(\mathrm{Pm04859}, \mathrm{E}$-value $=6 \mathrm{e}-44)$, prolipoprotein diacylglyceryl transferase $(\mathrm{Pm04168}$, E-value $=2 \mathrm{e}-23)$ and alpha glucosidase $($ Pm03682 $(\mathrm{E}-$ value $=2 \mathrm{e}-44), \mathrm{Pm} 01066(\mathrm{E}-$ value $=2 \mathrm{e}-50)$ were also observed. In addition, Pfam domains for the glycosyltransferase family, Glyco_transf_20 (trehalose-6-phosphate transferase), Glyco_transf_22 (Alg9-like mannosyl transferase), Glyco_transf_28 (UDP-N-acetyl glucosaminine transferase and Glyco_transf_8 (lipopolysaccaride galactosyl transferase) were observed (Table 3). A single EST ORF encoding the domain called Alg14 (oligosaccharide biosynthesis protein Alg14 like), which represents an important protein in the synthesis of glycoconjugates, was also identified (Table 3). Prior studies have revealed glycosidase activity, including $\beta$-D-glucosidase, $\beta$ - $D$-xylosidase, $\mathrm{N}$-acetyl $\beta$-D-glucosaminidase and $\mathrm{N}$-acetyl $\beta$-D-galactosaminidase in Perkinsus trophozoites, and $\mathrm{N}$-acetyl $\beta$ D-glucosaminidase in spent culture medium (Ahmed, H., Fernández-Robledo, J.A., Vasta, G.R., unpublished results).

Three unique EST clusters (Pm03024 (E-value $=1 \mathrm{e}-36)$, Pm03327 (E-value $=1 \mathrm{e}-30)$ and Pm02250 (E-value $=7 \mathrm{e}-$ 26)) show similarity to the ERGIC-53-like mannose binding lectin also present in Cryptosporidium, Toxoplasma and Plasmodium species. ERGIC-53 is a type 1 transmembrane L-type lectin present in the endoplasmic reticulum (ER) that captures correctly folded glycoproteins, and mediates their transport along the secretory pathway. The yeast L-lectins Emp46p and EMP47p, homologues of ERGIC-53, have been proposed to be transport receptors that facilitate recruitment of glycoproteins into vesicles budding from the ER [99]. One unique sequence $(\mathrm{Pm} 04230$, $\mathrm{E}$-value $=7 \mathrm{e}-12)$ shows similarity to the mannose-binding lectin derived from $\mathrm{Cri}$ num asiaticum, a plant lectin with homologies to known monocot mannose-binding lectins from Amaryllidaceae, Orchidaceae, Alliaceae and Liliaceae, high similarity to the gastrodianin-type antifungal proteins and a predicted structure similar to that of the Galanthus nivalis agglutinin [100]. The sequence Pm07056 shows similarity to a galactose-specific lectin. Pfam analysis also detected similarities with plant lectins, such as domains for the ricintype beta-trefoil lectin and legume-like-lectin (Table 3).

\section{Nucleotide metabolism}

Several nucleotide salvage enzymes were identified. Hypoxanthine-guanine phosphoribosyl transferase, HGPRT (Pm04986, E-value = 2e-57), and hypoxanthinexanthine-guanine phosphoribosyl transferase, HXGPRT $(\mathrm{Pm} 07697, \mathrm{E}$-value $=6 \mathrm{e}-53)$; uridine kinase - uracil phosphoribosyltransferase, UK-UPRT (Pm01230, E-value = 1e-40) and uracil phosphoribosyltransferase, UPRT $(P m 07824$, E-value $=2 \mathrm{e}-43)$ were detected. Pfam analysis revealed the presence of phosphoribosyl transferase in 3 ESTs including Pm04986 (Table 3). Evidence for a few de novo biosynthetic enzymes was detected. There is a hit to dihydroorotate oxidase $(P m 05343$, E-value $=7 \mathrm{e}-30)$, uridylate kinase $(\mathrm{Pm} 05827, \mathrm{E}$-value $=3 \mathrm{e}-19)$ and adenylosuccinate synthetase $(\mathrm{Pm02370}, \mathrm{E}-\mathrm{value}=1 \mathrm{e}-128)$ all involved in pyrimidine biosynthesis. Pfam analysis also revealed an adenylosuccinate synthetase domain in Pm02370.

\section{Potential targets for chemotherapy}

Several potential candidates for chemotherapy in P. marinus were identified in this EST study. Like the proteases from other parasites, known to degrade host proteins for acquisition of the nutrients, proteases produced by $P$. marinus could be targeted for chemotherapy. Further, the plasma of the eastern oyster $C$. virginica contains a serine protease inhibitor that binds tightly to subtilisin and perkinsin, and is potentially involved in blocking the parasite's proteolytic activity [84]. Therefore, dermo diseaseresistant oyster populations could be established by introducing through selective breeding selected gene variants that exhibit enhanced expression of protease inhibitors. Further, based on the observed in vitro susceptibility of 
Table 5: P. marinus sequences with similarity to known oxidative enzymes.

\begin{tabular}{|c|c|c|c|c|}
\hline Protein & $\begin{array}{l}\text { P. marinus EST } \\
\text { cluster ID }\end{array}$ & $\begin{array}{l}\text { GenBank best hit } \\
\text { accession }\end{array}$ & E-value & $\begin{array}{l}\text { Species with best } \\
\text { blast hit }\end{array}$ \\
\hline \multirow[t]{2}{*}{ Superoxide dismutase 1} & Pm00420 & $\underline{\text { AY095212 }}$ & $5 e-79$ & Perkinsus marinus \\
\hline & Pm05057 & AY095212 & $1 e-78$ & Perkinsus marinus \\
\hline Superoxide dismutase 2 & Pm05920 & $\underline{\text { AY095213 }}$ & $1 e-154$ & Perkinsus marinus \\
\hline \multirow[t]{5}{*}{ Thioredoxin } & Pm03850 & $\underline{X 80887}$ & $1 e-17$ & $\begin{array}{l}\text { Chlamydomonas } \\
\text { reinhardtii }\end{array}$ \\
\hline & Pm07686 & $\underline{\mathrm{BAB} 02711}$ & $7 e-12$ & Arabidopsis thaliana \\
\hline & Pm02203 & $\underline{\text { EEB00121 }}$ & $1 e-120$ & Toxoplasma gondii \\
\hline & Pm01102 & EEF45000 & $2 e-06$ & Ricinus communis \\
\hline & Pm04526 & NP 001148952 & $1 \mathrm{e}-08$ & Zea mays \\
\hline Peroxiredoxin 6 & Pm01619 & NP 001034418 & $2 e-67$ & Gallus gallus \\
\hline Peroxiredoxin V & Pm01453 & $\underline{A B V 22156}$ & $3 e-75$ & Perkinsus chesapeaki \\
\hline \multirow[t]{4}{*}{ Glutaredoxin } & Pm06883 & ABV22433 & $9 e-16$ & Oxyrrhis marina \\
\hline & Pm07604 & NP 490812 & $2 \mathrm{e}-27$ & $\begin{array}{l}\text { Caenorhabditis } \\
\text { elegans }\end{array}$ \\
\hline & Pm04444 & $\underline{X P \quad 002125050}$ & $4 e-28$ & Ciona intestinalis \\
\hline & Pm07679 & $\underline{X P \quad 002181580}$ & $2 e-20$ & $\begin{array}{l}\text { Phaeodactylum } \\
\text { tricornutum }\end{array}$ \\
\hline Glutathione reductase & Pm04212 & $\underline{X P \quad 002296324}$ & $1 e-112$ & $\begin{array}{l}\text { Thalassiosira } \\
\text { pseudonana }\end{array}$ \\
\hline \multirow[t]{3}{*}{ Thioredoxin reductase } & Pm07484 & $\underline{\text { Gl:15826813 }}$ & $7 e-54$ & Rattus norvegicus \\
\hline & Pm02868 & $\underline{\text { EEB11260 }}$ & $1 e-78$ & $\begin{array}{l}\text { Pediculus humanus } \\
\text { corporis }\end{array}$ \\
\hline & Pm04212 & XP 002296324 & $1 e-112$ & $\begin{array}{l}\text { Thalassiosira } \\
\text { pseudonana }\end{array}$ \\
\hline
\end{tabular}

the parasite to selected ROIs [73] and hemocyte-based defense against the parasite in vivo [101], therapeutic agents could be applied to infected oysters to enhance their respiratory burst in response to $P$. marinus. Similarly, and based on the observation that parasites are usually more susceptible to ROIs than are their hosts, components of the $P$. marinus anti-oxidative stress pathway could be the basis for development of therapeutic drugs. Conventional molecular modeling approaches such as the Drug Design by Receptor Fit (DDRF) methods can be applied to the parasite enzymes such as glutathione reductase, peroxiredoxin, thioredoxin, and glutaredoxins, whose sequences were identified in this study. The $P$. marinus EST analysis also identified sequences similar to aldolase, an enzyme that has been used as a target for therapy in several Plasmodium species because of its central role in energy metabolism (glycolysis) [102]. Aldolases have been also used for intervention in Trypanosoma brucei infection [103]. Therefore, the potential for aldolase inhibitors, already in use for other parasites, to inhibit $P$. marinus growth in vitro warrants further investigation. The recent characterization of the isoprenoid pathway in $P$. marinus strongly suggests the presence of a cryptic plastid in the parasite, which has been identified as an excellent target for drug therapy in apicomplexan parasites [104-107]. Analytical methods [77] as well as EST evidence from the current study point towards the presence of a DOXP/ME pathway (Table 5) to produce isopentenyl diphosphate. The enzymatic machinery of the DOXP/MEP pathway in 
Table 6: P. marinus consensus sequences with similarity to enzymes involved in plastid isoprenoid metabolism and other plant-type plastid proteins.

\begin{tabular}{|c|c|c|c|c|}
\hline Protein & $\begin{array}{l}\text { P. marinus EST } \\
\text { Cluster ID }\end{array}$ & $\begin{array}{l}\text { GenBank best hit } \\
\text { accession }\end{array}$ & E-value & Species with best hit \\
\hline $\begin{array}{l}\text { 2C-methyl-D-erythritol } \\
\text { 2,4-cyclodiphosphate } \\
\text { synthase }\end{array}$ & Pm01490 & $\underline{B A G 14388}$ & $1 e-123$ & Perkinsus marinus \\
\hline \multirow{3}{*}{$\begin{array}{l}\text { 4-hydroxy-3-methyl-2- } \\
\text { butenyl 1-diphosphate } \\
\text { synthase }\end{array}$} & Pm02434 & $\underline{\text { BAG14389 }}$ & $1 e-167$ & Perkinsus marinus \\
\hline & Pm02620 & $\underline{\text { BAG14389 }}$ & $1 e-147$ & Perkinsus marinus \\
\hline & Pm07308 & BAG14389 & $1 e-145$ & Perkinsus marinus \\
\hline $\begin{array}{l}\text { Triose phosphate/ } \\
\text { phosphate } \\
\text { translocator, non- } \\
\text { green plastid, } \\
\text { chloroplast precursor, } \\
\text { putative }\end{array}$ & Pm05421 & EEF36488 & $1 e-18$ & Ricinus communis \\
\hline \multirow{3}{*}{$\begin{array}{l}\text { 1-deoxy-D-xylulose-5- } \\
\text { phosphate synthase }\end{array}$} & Pm01411 & $\underline{B A G 14385}$ & 0.00 & Perkinsus marinus \\
\hline & Pm01258 & $\underline{B A G 14385}$ & $1 e-160$ & Perkinsus marinus \\
\hline & Pm01490 & BAG14385 & 1e-154 & Perkinsus marinus \\
\hline \multirow[t]{2}{*}{$\begin{array}{l}\text { Cytidylyltransferase } \\
\text { family protein }\end{array}$} & Pm07765 & XP 001015603 & $1 e-24$ & $\begin{array}{l}\text { Tetrahymena } \\
\text { thermophila }\end{array}$ \\
\hline & Pm03879 & $\underline{X P \quad 001015603}$ & $2 e-24$ & $\begin{array}{l}\text { Tetrahymena } \\
\text { thermophila }\end{array}$ \\
\hline $\begin{array}{l}\text { 2-C-methyl-D- } \\
\text { erythritol 4-phosphate } \\
\text { cytidylyltransferase }\end{array}$ & Pm05015 & YP 007326 & $9 e-26$ & $\begin{array}{l}\text { Candidatus } \\
\text { Protochlamydia } \\
\text { amoebophila }\end{array}$ \\
\hline Ferredoxin, putative & Pm01110 & CAK51557 & $9 e-53$ & Perkinsus marinus \\
\hline $\begin{array}{l}\text { Ferredoxin-NADP } \\
\text { reductase }\end{array}$ & Pm04555 & YP 001516374 & $1 e-62$ & Acaryochloris marina \\
\hline
\end{tabular}

Plasmodium falciparum has been fully characterized [108] and fosmidomycin, a specific inhibitor of the DOXP reductoisomerase, is very effective against malaria [109]. Interestingly, fosmidomycin has also been tested against Perkinsus trophozoites and it appears that up to 5 days concentrations up to $1 \mathrm{mM}$ show no effect on growth inhibition [25]. The genes for the DOXP pathway are present in Toxoplasma and it has been proposed [110] that toxoplasmosis could be treated by targeting a downstream pathway enzyme, farnesyl diphosphate synthase (FPPS), using bisphosphonates, which are specific FPPS inhibitors. A similar strategy could also be applied to dermo disease if bisphosphonates do not affect the oyster or if fosmidomycin does not show differential effectiveness against the parasite DOXP pathway. Therapeutic strategies using existing drugs such as bisphosphonates 


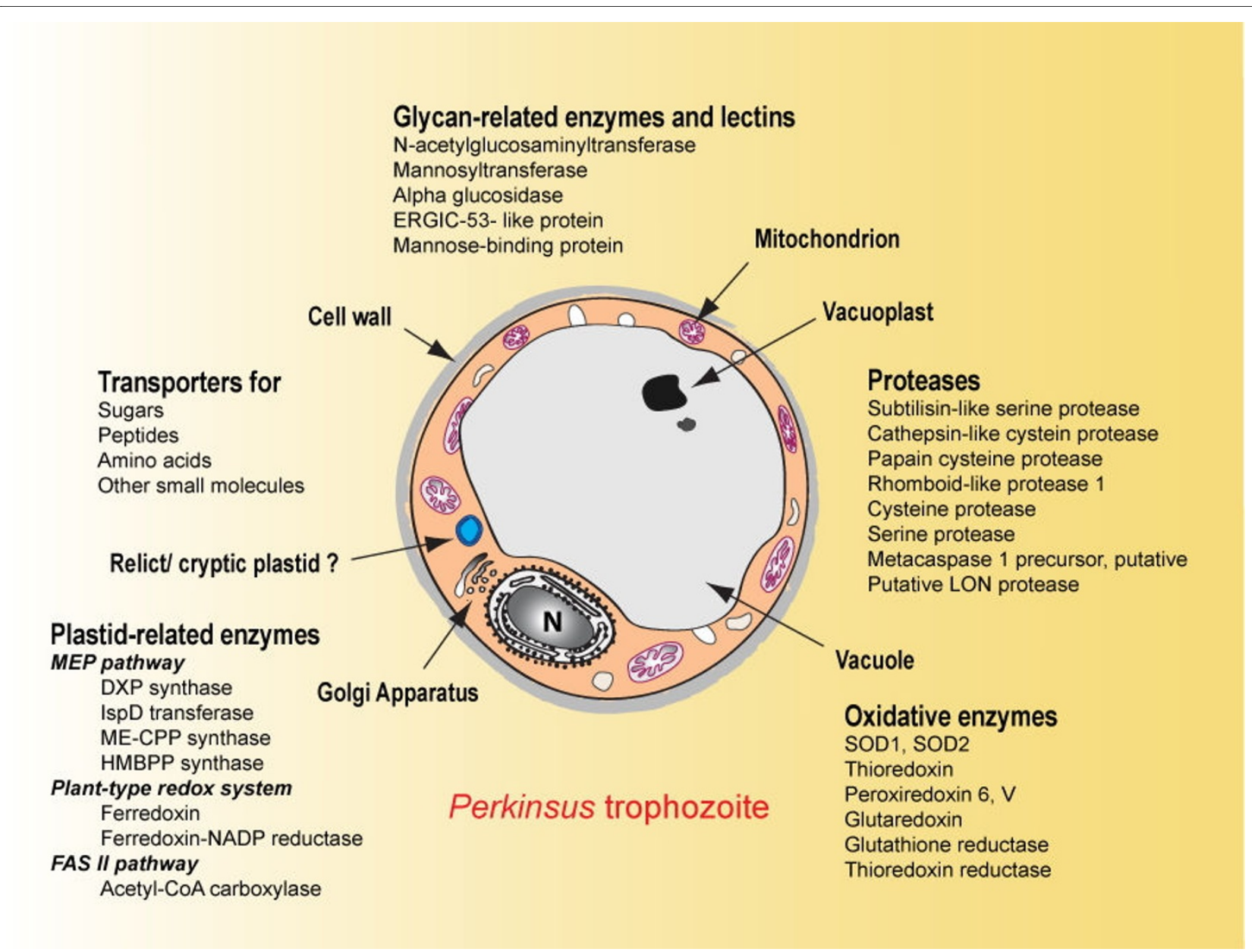

Figure 4 Biological role(s) of $P$. marinus sequences of particular interest. Several aspects of Perkinsus biology are highlighted, including the identification of pathways indicative of a relict/cryptic plastid, expression of numerous transporters and proteases likely be involved in the uptake of nutrients and the degradation of host components, enzymes and lectins involved in glycan assembly, protein folding and secretion, and parasite-host interactions.

and fosmidomycin have the advantage of avoiding costs of de novo drug design and development. Moreover, virtual screening initiatives could provide new avenues for drug development against numerous protozoan parasites [111]. Conversely, these observations also highlight the potential for using $P$. marinus as a readily-cultured, nonpathogenic model for early screening of potential drugs against a variety of protistan human parasites.

\section{Conclusions}

By providing a first glimpse into expression of genes encoding proteins associated with important metabolic pathways in other parasitic protozoa, such as proteases, oxidative stress enzymes, fatty-acid synthesis and isoprenoid metabolism, the sequences generated from the $P$. marinus cDNA libraries are extremely informative. The identification of proteins implicated in glycan assembly, protein folding and secretion, and parasite-host interactions, and those that participate in biochemical pathways associated with a putative relict plastid, suggest that potential chemotherapy targets that have been proven to be effective in other protozoan parasites are also expressed in P. marinus and could lead to novel intervention strategies for dermo disease (Figure 4).

P. marinus sequences display the greatest similarity to EST sequences from dinoflagellates. No significant differences were observed between EST populations obtained from parasites propagated under standard conditions and those exposed to oyster serum. This finding is a consequence of the small number of ESTs sampled, and a more rigorous analysis should be carried out by expanding both sample size and incorporating additional experimental strategies. Concerning the latter, to gain a better understanding $P$. marinus virulence, approaches such as subtractive techniques $[112,113]$ and microarray analysis will be very useful. Although our results are a first step in that direction, the application of subtractive techniques should result in ESTs overlooked in our study due to the 
limitations of non-normalized libraries. The libraries and ESTs generated here, however, may find further use in the production of microarrays to visualize changes in gene expression, such as expression of parasite genes related to defense against the oyster's immune system.

As indicated above, $P$. marinus expresses sequences with significant similarity of dinoflagellates followed by the apicomplexans. Although the fraction of $P$. marinus transcripts that are trans-spliced is still unknown, the identification of a SL in $>14 \%$ of the ESTs confirms the previously established affinity with dinoflagellates. It also suggests that PCR amplification based on the Perkinsus variant of the SL would provide a rapid and efficient method of amplifying and cloning full-length transcripts in the future.

The EST analysis reported herein, together with the recently completed $P$. marinus genome sequencing project (GenBank Project ID: 12736), and the development of a transfection system for Perkinsus trophozoites [40] will enhance the community's ability to improve the status of both natural and farmed oyster stocks by identifying gene products suitable for drug targeting, which will lead to therapeutic applications that may be effective in closed (especially hatchery) systems. The genes relevant to hostparasite interactions, particularly those involved in hostcell entry and/or pathway signaling may lead to genetically-selected or -engineered oysters that either block the entry of the parasite or enhance the response of the oyster defense against $P$. marinus. Production of seed oysters that remain disease-free and reach marketable size will be critical for full recovery of wild eastern oyster populations, which provide irreplaceable environmental services. Disease-resistant oysters would also form the basis of a viable shellfishery, as well as sustainable production of farmed oysters.

\section{Additional material}

Additional file 1 Perkinsus marinus EST cluster consensus and singleton sequences. This file contains Fasta-formatted files of 7,863 P. marinus EST cluster consensus and singleton sequences with the cluster ID numbers assigned in this study.

Additional file 2 Supplemental information for the analyses described in the text. This file contains the names of the annotated genomes used in the phylogenetic analysis, a BLASTX analysis of P. marinus EST, the number of sequences in NCBI for each taxonomic group, and the number of orthologous groups and protein sequences within each group that are shared with P. marinus. Supplemental Table S1. List of 21 annotated genomes used in the phylogenetic analysis. Supplemental Table S2. Results of BLASTX analysis of ESTs from standard and serum-supplemented medium. Supplemental Table S3. The distribution of sequences present in the NCBI nr and dbEST databases by taxonomic group mentioned in this study. Supplemental Table S4. The number of orthologous groups and the number of protein sequences within each group that are shared with $P$. marinus by varying the number of taxa.

\section{Authors' contributions}

SJJ - Performed most bioinformatics analyses and spliced-leader analyses, and contributed to the phylogenetic analyses and writing of the manuscript; JAFR Participated in the conception of the EST project, subcloned the parasite and obtained the materials for construction of the libraries, generated the first batches of ESTs, analyzed biochemical pathways, and contributed to the writing of the manuscript; MJG - provided oversight of the EST project at JCVI/TIGR; NME - Provided oversight of the EST project at JCVI/TIGR, and submitted data to GenBank; CHK - wrote the PERL pipeline and performed most phylogenetic analyses; EJS - generated the first batches of ESTs and provided comments on manuscript; HW - Clustered the ESTs; JCK - provided oversight for all bioinformatic, phylogenetic and SL analyses, and contributed to the writing of the manuscript; GRV - Conceived the EST project, provided oversight of experimental activities, contributed to the biochemical pathway analysis, and contributed to the writing of the manuscript. All authors read and approved the final manuscript.

\section{Acknowledgements}

Funding for this work was provided by NOAA - MD Sea Grant SA7528068-I to G.R.V and J.C.K, and in part by the NSF/USDA-CSREES Microbial Sequencing

Program (Award NSF/USDA 0333240) to M.J.G and N.M.E.S (JCVI), and G.R.V and J.A.F.R. (SOM/IMET) and by NSF Award IOS-0618409 to G.R.V. We thank Adam G. Marsh for making the initial P. marinus Lambda ZAP libraries, Dr. Jeremy DeBarry for useful discussions and Ganesh Srinivasamoorthy for help with PERL scripts and data parsing

\section{Author Details}

${ }^{1}$ Center for Tropical and Emerging Global Diseases, University of Georgia, Athens, GA 30602, USA, ${ }^{2}$ Department of Genetics, University of Georgia, Athens, GA 30602, USA, ${ }^{3}$ Department of Microbiology and Immunology, University of Maryland School of Medicine, IMET, Baltimore, MD 21202, USA, 4J. Craig Venter Institute, formerly Institute for Genomic Research, 9712 Medical Center Drive, Rockville, MD 20850, USA, ${ }^{5}$ Current address: Department of Medicine, Division of Infectious Diseases, Emory University School of Medicine, Atlanta, GA 30322, USA, ${ }^{6}$ Current address: Seattle Biomedical Research Institute, Seattle, WA 98109, USA, ${ }^{7}$ Current address: Department of Cell Biology and Molecular Genetics, University of Maryland, College Park, MD 20742, USA ${ }^{8}$ Current address: Department of Chemistry and Biochemistry, University of Arizona, Tucson, AZ 85721, USA and ${ }^{9}$ Current address: University of Maryland Center for Environmental Science, IMET, Baltimore, MD 21202, USA

Received: 21 August 2009 Accepted: 7 April 2010

Published: 7 April 2010

\section{References}

1. Ford SE: Range extension by the oyster parasite Perkinsus marinus into the northeastern United States: Response to climate change? J Shellfish Res 1996, 15(1):45-56.

2. Ford $S E$, Chintala MM: Northward expansion of a marine parasite: Testing the role of temperature adaptation. J Exp Mar Biol Ecol 2006, 339(2):226-235

3. Ford SE, Smolowitz R: Infection dynamics of an oyster parasite in its newly expanded range. Mar Biol 2007, 151(1):119-133.

4. Soniat TM: Epizootiology of Perkinsus marinus disease of eastern oysters in the Gulf of México. J Shellfish Res 1996, 15(1):35-43.

5. Reece KS, Siddall ME, Burreson EM, Graves JE: Phylogenetic analysis of Perkinsus based on actin gene sequences. J Parasitol 1997, 83(3):417-423.

6. Perkins FO: The structure of Perkinsus marinus (Mackin, Owen and Collier, 1950) Levine, 1978 with comments on taxonomy and phylogeny of Perkinsus spp. J Shellfish Res 1996, 15(1):67-87.

7. Levine ND: Perkinsus genus and other new taxa in the protozoan phylum Apicomplexa. J Parasitol 1978, 64(3):

8. Goggin CL, Barker SC: Phylogenetic position of the genus Perkinsus (Protista, Apicomplexa) based on small subunit ribosomal RNA. Mol Biochem Parasitol 1993, 60(1):65-70.

9. Siddall ME, Reece KS, Graves JE, Burreson EM: 'Total evidence' refutes the inclusion of Perkinsus species in the phylum Apicomplexa. Parasitology 1997, 115(Pt 2):165-176 
10. Kuvardina ON, Leander BS, Aleshin WV, Myl'nikov AP, Keeling PJ, Simdyanov TG: The phylogeny of colpodellids (Alveolata) using small subunit rRNA gene sequences suggests they are the free-living sister group to apicomplexans. J Eukaryot Microbiol 2002, 49(6):498-504.

11. Norén F, Moestrup $\varnothing$, Rehnstam-Holm AS: Parvilucifera infectans Norén et Moestrup gen. et sp. nov. (Perkinsozoa phylum nov.): A parasitic flagellate capable of killing toxic microalgae. Eur J Protist 1999, 35(3):233-254

12. Saldarriaga JF, McEan ML, Fast NM, Taylor FJR, Keeling PJ: Multiple protein phylogenies show that Oxyrrhis marina and Perkinsus marinus are early branches of the dinoflagellate lineage. Int J Syst Evol Microbiol 2003, 53:355-365

13. Gile GH, Patron NJ, Keeling PJ: EFL GTPase in cryptomonads and the distribution of EFL and EF-1alpha in chromalveolates. Protist 2006, 157(4):435-444

14. Hoppenrath M, Leander BS: Molecular phylogeny of Parvilucifera prorocentri (Alveolata, Myzozoa): Insights into perkinsid character evolution. J Eukaryot Microbiol 2009, 56(3):251-256.

15. Harvell CD, Kim K, Burkholder JM, Colwell RR, Epstein PR, Grimes DJ, Hofmann EE, Lipp EK, Osterhaus AD, Overstreet RM, et al:: Emerging marine diseases-climate links and anthropogenic factors. Science 1999, 285(5433):1505-1510

16. Villalba A, Reece KS, Ordas A, Casas SM, Figueras A: Perkinsosis in molluscs: A review. Aquat Living Res 2004, 17:411-432

17. Krantz GE, Jordan SJ: Management alternatives for protecting Crassostrea virginica fisheries in Perkinsus marinus enzootic and epizootic areas. J Shellfish Res 1996, 15(1):167-176.

18. Gauthier JD, Vasta GR: Continuous in vitro culture of the eastern oyster parasite Perkinsus marinus. J Invert Pathol 1993, 62(3):321-323.

19. Kleinschuster SJ, Swink SL: A simple method for the in vitro culture of Perkinsus marinus. Nautilus 1993, 107(2):76-78.

20. La Peyre JF, Faisal M, Burreson EM: In vitro propagation of the protozoan Perkinsus marinus, a pathogen of the eastern oyster, Crassostrea virginica. J Eukaryot Microbiol 1993, 40(3):304-310.

21. Faisal M, Schafhauser DY, Garreis KA, Elsayed E, La Peyre JF: Isolation and characterization of Perkinsus marinus proteases using bacitracinsepharose affinity chromatography. Comp Biochem Physiol, B 1999 123B(4):417-426.

22. Delaney MA, Brady YJ, Worley SD, Huels KL: The effectiveness of Nhalamine disinfectant compounds on Perkinsus marinus, a parasite of the eastern oyster Crassostrea virginica. J Shellfish Res 2003, 22(1):91-94.

23. Elandalloussi LM, Leite RB, Rodrigues PM, Afonso R, Nunes PA, Cancela ML: Effect of antiprotozoal drugs on the proliferation of the bivalve parasite Perkinsus olseni. Aquaculture 2005, 243(1-4):9-17.

24. Lund ED, Soudant P, Chu F-LE, Harvey E, Bolton S, Flowers A: Effects of Triclosan on growth, viability and fatty acid synthesis of the oyster protozoan parasite Perkinsus marinus. Dis Aquat Org 2005, 67(3):217-224

25. Stelter K, El-Sayed NM, Seeber F: The expression of a plant-type ferredoxin redox system provides molecular evidence for a plastid in the early dinoflagellate Perkinsus marinus. Protist 2007, 158(1):119-130.

26. Teles-Grilo ML, Tato-Costa J, Duarte SM, Maia A, Casal G, Azevedo C: Is there a plastid in Perkinsus atlanticus (Phylum Perkinsozoa)? Eur J Protistol 2007, 43(2):163-167.

27. Venegas-Caleron M, Beaudoin F, Sayanova O, Napier JA: Co-transcribed genes for long chain polyunsaturated fatty acid biosynthesis in the protozoon Perkinsus marinus include a plant-like FAE1 3-ketoacyl coenzyme A synthase. J Biol Chem 2007, 282(5):2996-3003.

28. Tasumi S, Vasta GR: A galectin of unique domain organization from hemocytes of the eastern oyster (Crassostrea virginica) Is a receptor for the protistan parasite Perkinsus marinus. J Immunol 2007, 179(5):3086-3098

29. Vasta GR: Roles of galectins in infection. Nat Rev Microbio/ 2009, 7:424-438.

30. Volety AK, Chu FL: Suppression of chemiluminescence of eastern oyster (Crassostrea virginica) hemocytes by the protozoan parasite Perkinsus marinus. Dev Comp Immunol 1995, 19(2):135-142.

31. Anderson RS: Perkinsus marinus secretory products modulate superoxide anion production by oyster (Crassostrea virginica) haemocytes. Fish Shellfish Immunol 1999, 9(1):51-60.

32. Alavi MR, Fernández-Robledo JA, Vasta GR: In vitro intracellular survival of Perkinsus marinus trophozoites upon phagocytosis by oyster
(Crassostrea virginica and Crassostrea ariakensis) hemocytes. J Parasitol 2009:1.

33. Chu F-LE: Laboratory investigations of susceptibility, infectivity, and transmission of Perkinsus marinus in oysters. J Shellfish Res 1996, 15(1):57-66

34. Adams MD, Kerlavage AR, Fleischmann RD, Fuldner RA, Bult CJ, Lee NH, Kirkness EF, Weinstock KG, Gocayne JD, White O, et al:: Initial assessment of human gene diversity and expression patterns based upon 83 million nucleotides of cDNA sequence. Nature 1995, 377(6547 Suppl):3-174

35. Ajioka JW, Boothroyd JC, Brunk BP, Hehl A, Hillier L, Manger ID, Marra M, Overton GC, Roos DS, Wan KL, et al:: Gene discovery by EST sequencing in Toxoplasma gondii reveals sequences restricted to the Apicomplexa. Genome Res 1998, 8(1):18-28

36. Prichard $R$, Tait $A$ : The role of molecular biology in veterinary parasitology. Vet Parasito/ 2001, 98(1-3):169-194.

37. Tarleton RL, Kissinger J: Parasite genomics: current status and future prospects. Curr Opin Immunol 2001, 13(4):395-402.

38. Pappas GJ Jr, Benabdellah K, Zingales B, Gonzalez A: Expressed sequence tags from the plant trypanosomatid Phytomonas serpens. Mol Biochem Parasitol 2005, 142(2):149-157

39. Gauthier JD, Vasta GR: In vitro culture of the eastern oyster parasite Perkinsus marinus: Optimization of the methodology. J Invert Pathol 1995, 66(2):156-168.

40. Fernández-Robledo JA, Lin Z, Vasta GR: Transfection of the protozoan parasite Perkinsus marinus. Mol Biochem Parasitol 2008, 157(1):44-53.

41. Gauthier JD, Vasta GR: Effects of plasma from bivalve mollusk species on the in vitro proliferation of the protistan parasite Perkinsus marinus. $J$ Exp Zool 2002, 292(3):221-230.

42. Sambrook J, Russell DW: Molecular Cloning A Laboratory Manual. Third edition. New York: CHSL Press; 2001

43. Rice P, Longden I, Bleasby A: EMBOSS: the European Molecular Biology Open Software Suite. Trends Genet 2000, 16(6):276-277.

44. Pertea G, Huang X, Liang F, Antonescu V, Sultana R, Karamycheva S, Lee Y, White J, Cheung F, Parvizi B, et al:: TIGR Gene Indices clustering tools (TGICL): a software system for fast clustering of large EST datasets. Bioinformatics 2003, 19(5):651-652

45. Altschul SF, Gish W, Miller W, Myers EW, Lipman DJ: Basic local alignment search tool. J Mol Biol 1990, 215(3):403-410.

46. He J, Dai X, Zhao X: PLAN: a web platform for automating highthroughput BLAST searches and for managing and mining results. BMC Bioinformatics 2007, 8:53.

47. Li L, Stoeckert CJ Jr, Roos DS: OrthoMCL: identification of ortholog groups for eukaryotic genomes. Genome Res 2003, 13(9):2178-2189.

48. Thompson JD, Higgins DG, Gibson TJ: Clustal-W - Improving the Sensitivity of Progressive Multiple Sequence Alignment through Sequence Weighting, Position-Specific Gap Penalties and Weight Matrix Choice. Nucl Acids Res 1994, 22(22):4673-4680.

49. Castresana J: Selection of conserved blocks from multiple alignments for their use in phylogenetic analysis. Mol Biol Evol 2000, 17(4):540-552.

50. Felsenstein J: Phylogeny Inference Package (PHYLIP). In Version 3.5c edn Seattle: University of Washington, Seattle, Washington; 1993.

51. Li L, Brunk BP, Kissinger JC, Pape D, Tang K, Cole RH, Martin J, Wylie T, Dante M, Fogarty SJ, et al:: Gene discovery in the apicomplexa as revealed by EST sequencing and assembly of a comparative gene database. Genome Res 2003, 13(3):443-454.

52. Leggat W, Hoegh-Guldberg O, Dove S, Yellowlees D: Analysis of an EST library from the dinoflagellate (Symbiodinium sp.) symbiont of reefbuilding corals. J Phycol 2007, 43(5):1010-1021.

53. Coss CA, Robledo JA, Ruíz GM, Vasta GR: Description of Perkinsus andrewsi n. sp. isolated from the Baltic clam (Macoma balthica) by characterization of the ribosomal RNA locus, and development of a species-specific PCR-based diagnostic assay. J Eukaryot Microbiol 2001 48(1):52-61.

54. Coss CA, Robledo JA, Vasta GR: Fine structure of clonally propagated in vitro life stages of a Perkinsus sp. isolated from the Baltic clam Macoma balthica. J Eukaryot Microbiol 2001, 48(1):38-51.

55. Ellis JT, Morrison DA, Jeffries AC: The phylum Apicomplexa: an update on the molecular phylogeny. Boston: Kluwer Academis Publishers; 1998.

56. Leander BS, Clopton RE, Keeling PJ: Phylogeny of gregarines (Apicomplexa) as inferred from small-subunit rDNA and beta-tubulin. Int J Syst Evol Microbiol 2003, 53(Pt 1):345-354 
57. Hackett JD, Scheetz TE, Yoon HS, Soares MB, Bonaldo MF, Casavant TL, Bhattacharya D: Insights into a dinoflagellate genome through expressed sequence tag analysis. BMC Genomics 2005, 6(1):80.

58. Erdner DL, Anderson DM: Global transcriptional profiling of the toxic dinoflagellate Alexandrium fundyense using Massively Parallel Signature Sequencing. BMC Genomics 2006, 7:88.

59. Lidie KB, Ryan JC, Barbier M, Van Dolah FM: Gene expression in Florida red tide dinoflagellate Karenia brevis: analysis of an expressed sequence tag library and development of DNA microarray. Mar Biotechnol (NY) 2005, 7(5):481-493.

60. Bachvaroff TR, Concepcion GT, Rogers CR, Herman EM, Delwiche CF: Dinoflagellate expressed sequence tag data indicate massive transfer of chloroplast genes to the nuclear genome. Protist 2004, 155(1):65-78.

61. Tanikawa N, Akimoto H, Ogoh K, Chun W, Ohmiya Y: Expressed sequence tag analysis of the dinoflagellate Lingulodinium polyedrum during dark phase. Photochem Photobiol 2004, 80:31-35.

62. Adl SM, Simpson AG, Farmer MA, Andersen RA, Anderson OR, Barta JR, Bowser SS, Brugerolle G, Fensome RA, Frederica S, et al:: The new higher level classification of eukaryotes with emphasis on the taxonomy of protists. J Eukaryot Microbiol 2005, 52(5):399-451.

63. Zhang H, Hou Y, Miranda L, Campbell DA, Sturm NR, Gaasterland T, Lin S: Spliced leader RNA trans-splicing in dinoflagellates. Proc Natl Acad SCi USA 2007, 104(11):4618-4623.

64. Slamovits $\mathrm{CH}$, Keeling PJ: Widespread recycling of processed cDNAs in dinoflagellates. Curr Biol 2008, 18(13):R550-552.

65. Zhang H, Lin S: Retrieval of missing spliced leader in dinoflagellates. PLoS One 2009, 4(1):e4129.

66. Wan KL, Blackwell JM, Ajioka JW: Toxoplasma gondii expressed sequence tags: insight into tachyzoite gene expression. Mol Biochem Parasitol 1996, 75(2):179-186.

67. Strong WB, Nelson RG: Preliminary profile of the Cryptosporidium parvum genome: an expressed sequence tag and genome survey sequence analysis. Mol Biochem Parasitol 2000, 107(1):1-32.

68. Wan KL, Chong SP, Ng ST, Shirley MW, Tomley FM, Jangi MS: A survey of genes in Eimeria tenella merozoites by EST sequencing. Int J Parasitol 1999, 29(12):1885-1892.

69. Asojo OA, Schott EJ, Vasta GR, Silva AM: Structures of PmSOD1 and PmSOD2, two superoxide dismutases from the protozoan parasite Perkinsus marinus. Acta Crystallogr Sect F Struct Biol Cryst Commun 2006, 62(Pt 11):1072-1075.

70. Ahmed H, Schott EJ, Gauthier JD, Vasta GR: Superoxide dismutases from the oyster parasite Perkinsus marinus: purification, biochemical characterization, and development of a plate microassay for activity. Anal Biochem 2003, 318(1):132-141.

71. Schott EJ, Vasta GR: The PmSOD1 Gene of the protistan parasite Perkinsus marinus complements the sod $2 \Delta$ mutant of Saccharomyces cerevisiae, and directs an iron superoxide dismutase to mitochondria. Mol Biochem Parasitol 2003, 126(1):81-92.

72. Schott EJ, Robledo JAF, Wright AC, Silva AM, Vasta GR: Gene organization and homology modeling of two iron superoxide dismutases of the early branching protist Perkinsus marinus. Gene 2003, 309(1):1-9.

73. Schott EJ, Pecher WT, Okafor F, Vasta GR: The protistan parasite Perkinsus marinus is resistant to selected reactive oxygen species. Exp Parasitol 2003, 105(3-4):232-240.

74. Wright A, Ahmed H, Gauthier J, Silva A, Vasta G: cDNA cloning and characterization of two iron superoxide dismutases from the oyster parasite Perkinsus marinus. Mol Biochem Parasitol 2002, 123(1):73.

75. Matsuzaki M, Kita K, Nozaki H: Orthologs of plastid isoplenoids biosynthesis pathway genes from Perkinsus. J Plant Res 2006, 119(suppl):122

76. Grauvogel C, Reece KS, Brinkmann H, Petersen J: Plastid isoprenoid metabolism in the oyster parasite Perkinsus marinus connects dinoflagellates and malaria pathogens-new impetus for studying alveolates. J Mol Evol 2007, 65(6):725-729.

77. Matsuzaki M, Kuroiwa H, Kuroiwa T, Kita K, Nozaki H: A cryptic algal group unveiled: a plastid biosynthesis pathway in the oyster parasite Perkinsus marinus. Mol Biol Evol 2008, 25(6):1167-1179.

78. Earnhart CG, Kaattari SL: Potential novel epitopes in the extracellular products of oyster homogenate-supplemented Perkinsus marinus cells are not detected by subtractive immunization. J Parasito/ 2005, 91(3):689-691
79. Maclntyre EA, Earnhart CG, Kaattari SL: Host oyster tissue extracts modulate in vitro protease expression and cellular differentiation in the protozoan parasite, Perkinsus marinus. Parasitology 2003, 126(Pt 4):293-302.

80. Romestand B, Corbier F, Roch P: Protease inhibitors and haemagglutinins associated with resistance to the protozoan parasite, Perkinsus marinus, in the Pacific oyster, Crassostrea gigas. Parasitology 2002, 125(Pt 4):323-329

81. Faisal M, Maclntyre EA, Adham KG, Tall BD, Kothary MH, La Peyre JF: Evidence for the presence of protease inhibitors in eastern (Crassostrea virginica) and Pacific (Crassostrea gigas) oysters. Comp Biochem Physiol, B 1998, 121B(2):161-168.

82. Oliver JL, Lewis TD, Faisal M, Kaattari SL: Analysis of the effects of Perkinsus marinus proteases on plasma proteins of the eastern oyster (Crassostrea virginica) and the Pacific oyster (Crassostrea gigas). J Invertebr Pathol 1999, 74(2):173-183.

83. La Peyre JF, Schafhauser DY, Rizkalla EH, Faisal M: Production of serine proteases by the oyster pathogen Perkinsus marinus (Apicomplexa) in vitro. J Eukaryot Microbiol 1995, 42(5):544-551.

84. Xue QG, Waldrop GL, Schey KL, Itoh N, Ogawa M, Cooper RK, Losso JN, La Peyre JF: A novel slow-tight binding serine protease inhibitor from eastern oyster (Crassostrea virginica) plasma inhibits perkinsin, the major extracellular protease of the oyster protozoan parasite Perkinsus marinus. Comp Biochem Physiol B Biochem Mol Biol 2006, 145(1):16-26

85. Fernández-Robledo JA, Schott EJ, Vasta GR: Perkinsus marinus superoxide dismutase 2 (PmSOD2) localizes to single-membrane subcellular compartments. Biochem Biophys Res Commun 2008, 375(2):215-219.

86. Soudant P, Chu FL, Marty Y: Lipid class composition of the protozoan Perkinsus marinus, an oyster parasite, and its metabolism of a fluorescent phosphatidylcholine analog. Lipids 2000, 35(12):1387-1395.

87. Chu FL, Lund E, Soudant P, Harvey E: De novo arachidonic acid synthesis in Perkinsus marinus, a protozoan parasite of the eastern oyster Crassostrea virginica. Mol Biochem Parasitol 2002, 119(2):179-190.

88. Chu FL, Lund ED, Harvey E, Adlof R: Arachidonic acid synthetic pathways of the oyster protozoan parasite, Perkinsus marinus: evidence for usage of a delta-8 pathway. Mol Biochem Parasitol 2004, 133(1):45-51.

89. Lund ED, Chu FL, Soudant P, Harvey E: Perkinsus marinus, a protozoan parasite of the eastern oyster, has a requirement for dietary sterols. Comp Biochem Physiol A Mol Integr Physio/ 2007, 146(1):141-147.

90. Yu M, Kumar T, Nkrumah L, Coppi A, Retzlaff S, Li C, Kelly B, Moura P, Lakshmanan V, Freundlich J: The Fatty Acid Biosynthesis Enzyme Fabl Plays a Key Role in the Development of Liver-Stage Malarial Parasites. Cell host \& microbe 2008, 4(6):567-578.

91. Gardner MJ, Bishop R, Shah T, Villiers EP, Carlton JM, Hall N, Ren Q, Paulsen LT, Pain A, Berriman M, et al:: Genome sequences of Theileria parva, a bovine pathogen that transforms lymphocytes. Science 2005, 309(5731):134-137.

92. Weiss LM, Ma YF, Takvorian PM, Tanowitz HB, Wittner M: Bradyzoite development in Toxoplasma gondii and the hsp70 stress response. Infect Immun 1998, 66(7):3295-3302.

93. Lyons RE, Johnson AM: Gene sequence and transcription differences in $70 \mathrm{kDa}$ heat shock protein correlate with murine virulence of Toxoplasma gondii. Int J Parasitol 1998, 28(7):1041-1051.

94. Ivens AC, Lewis SM, Bagherzadeh A, Zhang L, Chan HM, Smith DF: A physical map of the Leishmania major Friedlin genome. Genome Res 1998, 8(2):135-145.

95. Sunila I, Hamilton RM, Dungan CF: Ultrastructural characteristics of the in vitro cell cycle of the protozoan pathogen of oysters, Perkinsus marinus. J Eukaryot Microbiol 2001, 48(3):348-361.

96. Vasta GR, Sullivan JT, Cheng TC, Marchalonis JJ, Warr GW: A cell membrane-associated lectin of the oyster hemocyte. J Invertbr Pathol 1982, 40:367-377

97. Vasta GR, Cheng TC, Marchalonis JJ: A lectin on the hemocyte membrane of the oyster (Crassostrea virginica). Cell Immunol 1984, 88(2):475-488

98. Gauthier JD, Jenkins JA, La Peyre JF: Flow cytometric analysis of lectin binding to in vitro-cultured Perkinsus marinus surface carbohydrates. J Parasitol 2004, 90(3):446-454

99. Sato K, Nakano A: Emp47p and its close homolog Emp46p have a tyrosine-containing endoplasmic reticulum exit signal and function in 
glycoprotein secretion in Saccharomyces cerevisiae. Mol Biol Cell 2002, 13(7):2518-2532.

100. Chai Y, Pang Y, Liao Z, Zhang L, Sun X, Lu Y, Wang S, Tang K: Molecular cloning and characterization of a mannose-binding lectin gene from Crinum asiaticum. J Plant Physiol 2003, 160(8):913-920.

101. Schirmer RH, Schollhammer T, Eisenbrand G, Krauth-Siegel RL: Oxidative stress as a defense mechanism against parasitic infections. Free Radic Res Commun 1987, 3(1-5):3-12

102. Wanidworanun C, Nagel RL, Shear HL: Antisense oligonucleotides targeting malarial aldolase inhibit the asexual erythrocytic stages of Plasmodium falciparum. Mol Biochem Parasitol 1999, 102(1):91-101.

103. Misset O, Bos OJ, Opperdoes FR: Glycolytic enzymes of Trypanosoma brucei. Simultaneous purification, intraglycosomal concentrations and physical properties. Eur J Biochem 1986, 157(2):441-453.

104. Fichera ME, Roos DS: A plastid organelle as a drug target in apicomplexan parasites. Nature 1997, 390(6658):407-409.

105. McFadden Gl, Roos DS: Apicomplexan plastids as drug targets. Trends Microbiol 1999, 7(8):328-333.

106. Soldati D: The apicoplast as a potential therapeutic target in and other apicomplexan parasites. Parasitol Today 1999, 15(1):5-7.

107. Wiesner J, Reichenberg A, Heinrich S, Schlitzer M, Jomaa H: The plastidlike organelle of apicomplexan parasites as drug target. Curr Pharm Des 2008, 14(9):855-871.

108. Wiesner J, Jomaa $\mathrm{H}$ : Isoprenoid biosynthesis of the apicoplast as drug target. Curr Drug Targets 2007, 8(1):3-13.

109. Jomaa H, Wiesner J, Sanderbrand S, Altincicek B, Weidemeyer C, Hintz M, Turbachova I, Eberl M, Zeidler J, Lichtenthaler HK, et al.: Inhibitors of the nonmevalonate pathway of isoprenoid biosynthesis as antimalarial drugs. Science 1999, 285(5433):1573-1576.

110. Moreno SN, Li ZH: Anti-infectives targeting the isoprenoid pathway of Toxoplasma gondii. Expert Opin Ther Targets 2008, 12(3):253-263.

111. de Azevedo WF Jr, Soares MB: Selection of targets for drug development against protozoan parasites. Curr Drug Targets 2009, 10(3):193-201

112. Yamagishi H, Garg V, Matsuoka R, Thomas T, Srivastava D: A molecular pathway revealing a genetic basis for human cardiac and craniofacial defects. Science 1999, 283(5405):1158-1161.

113. Dessens JT, Margos G, Rodriguez MC, Sinden RE: Identification of differentially regulated genes of Plasmodium by suppression subtractive hybridization. Parasitol Today 2000, 16(8):354-356.

doi: $10.1186 / 1471-2164-11-228$

Cite this article as: Joseph et al., The Alveolate Perkinsus marinus: Biological Insights from EST Gene Discovery BMC Genomics 2010, 11:228

Submit your next manuscript to BioMed Centra and take full advantage of:

- Convenient online submission

- Thorough peer review

- No space constraints or color figure charges

- Immediate publication on acceptance

- Inclusion in PubMed, CAS, Scopus and Google Scholar

- Research which is freely available for redistribution

Submit your manuscript at www.biomedcentral.com/submit
C Biomed Central 